


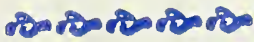

PLEASE HANDLE WITH CARE

University of

Connecticut Libraries

soratoros

35153 01224?71 6 

Digitized by the Internet Archive in 2011 with funding from

LYRASIS members and Sloan Foundation 


\title{
Tobacco Substation at Windsor Report for 1939
}

\author{
P. J. ANDERSON
}

T. R. Swanback and O. E. Street
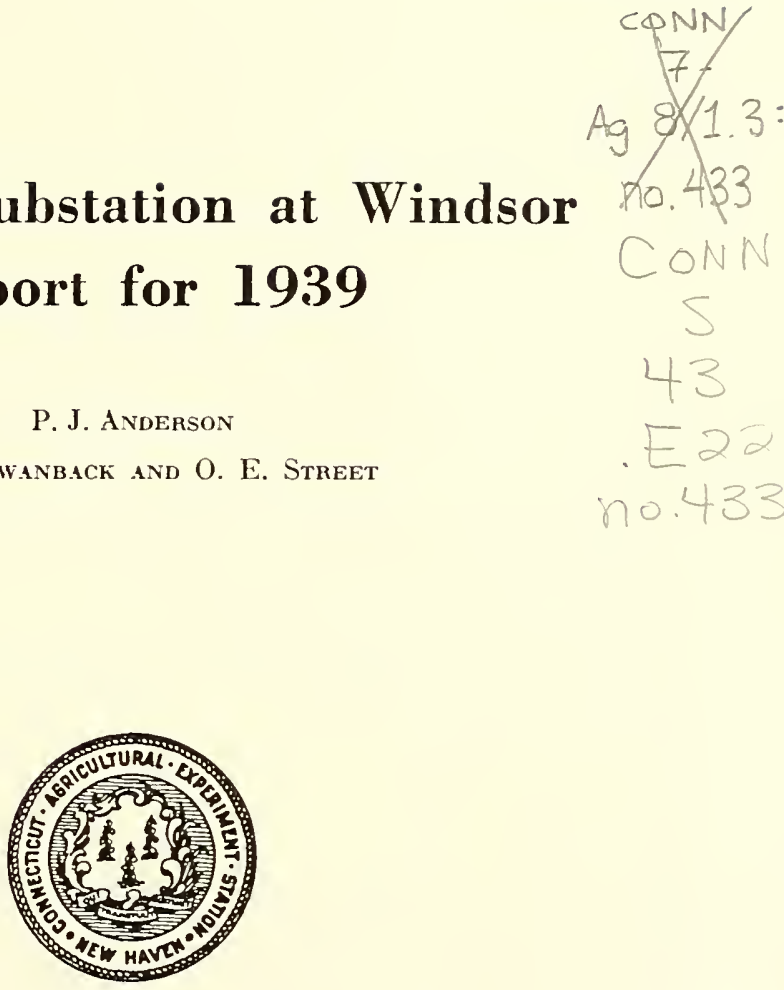

Uimmertirut

Âtricultural Tixperiment Station

Nou นq̣auen 



\section{TABLE OF CONTENTS}

Introduction and General Review of the Year................ 16 ?

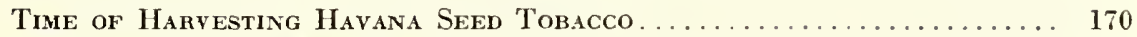

Summary of five years' tests.......................... 171

Variation in Chemical Composition of Leaves According to Their PosiTION ON THE STALK............................. 177

Report on the Insect Investigations for the 1939 Season............ 185

Experiments for the control of the potato flea beetle and the tobacco thrips

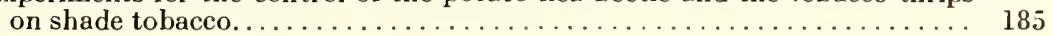

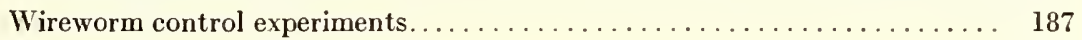

Insect abundance during $1939 \ldots \ldots \ldots \ldots \ldots \ldots \ldots \ldots \ldots \ldots \ldots$

Thrips and Flea Beetle Control Experiments................. 191

Further Experiments on the Control of Downy Mildew. . . . . . . . . . 193

Concentration of benzol gas required for control . . . . . . . . . . . . . . 194

Glass sash vs cloth covers. . . . . . . . . . . . . . . . . . . . . . 194

Dry cloth vs wet cloth................................ 196

Cloth covers over the glass.......................... 196

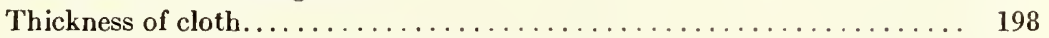

Sprinkling the glass sash with water. . . . . . . . . . . . . . . . 199

Effect of wind on benzol vapor concentration................. 201

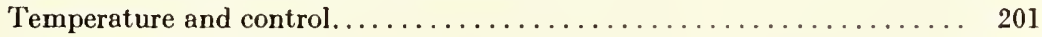

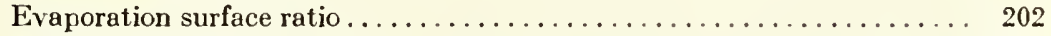

Wick evaporators for benzol............................ 204

Paradichlorobenzene.............................. 204

The Role of Yeast in the Fermentation of Tobacco............. 206

Further test on cigar binder types.................... 206 


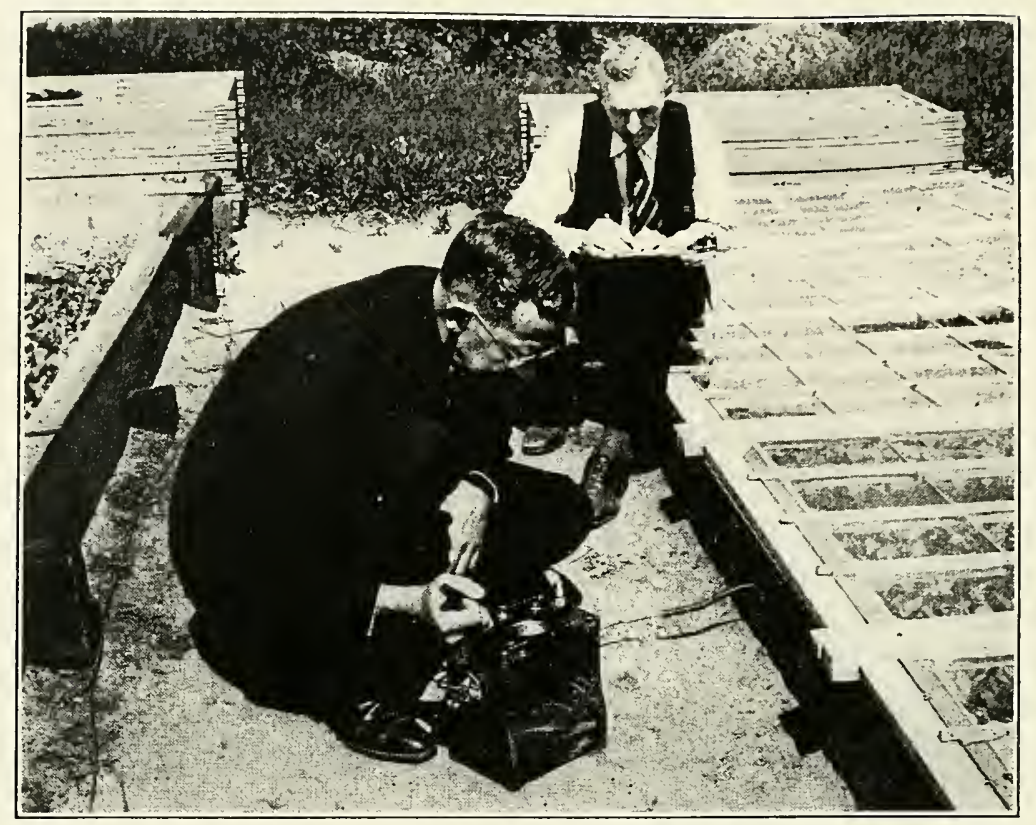

Figure 1. Measuring the concentration of benzol vapor in a bed with an M. S. A. Indicator. (Page 194.)

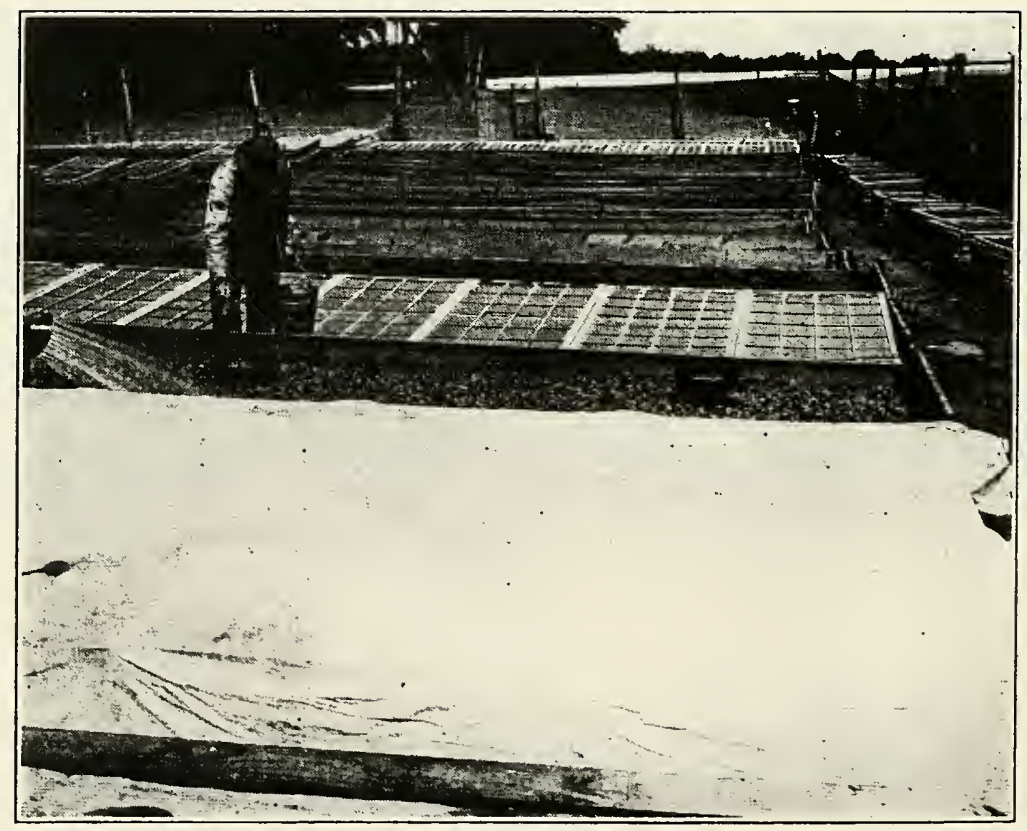

Figune 2. Gassing the beds. Grower in background pouring benzol into evaporating pans. Bed in foreground covered with cloth and being sprinkled with water from nozzle at left. (Page 202.) 


\title{
TOBACCO SUBSTATION AT WINDSOR
}

\author{
Report For 1939
}

\author{
P. J. Anderson, T. R. Swanback and O. E. Street
}

This, the Eighteenth Annual Report of the Tobacco Substation at 1 Windsor, comes at the close of a season that has been more favorable to the growers of all three types of tobacco than any year in the last decade. The growing season was somewhat dry: not too dry for good development of the crop, but dry enough to produce a heavy yield that is typical of seasons of less-than-average rainfall. Damage from hail or windstorms was confined to a few small areas in the tobacco section. Disease and insects took less than the usual toll. During the curing season, the weather was favorable to a good cure with a minimum of pole rot. A shortage of stocks in the hands of dealers and manufacturers, due to previous unfavorable seasons, resulted in fair prices paid to the growers for this year's crop.

One outstanding event of the year and an important

New Building forward step in Connecticut's tobacco investigations for was the erection of a new, larger and better building

Tobacco Research to house the laboratories, sorting rooms and offices of the Substation. At the time of writing, January 1, 1910, the building is not yet completed but will probably be ready for occupancy before the next field season starts. The work has long since outgrown the original small wooden building erected in 1922. Moreover, the old headquarters are not fireproof and offer no security for valuable research records, the most complete collection of photographic negatives on tobacco in New England, the excellent tobacco library and the scientific equipment assembled here. The new building, made of brick, concrete and steel is as fireproof as possible and will insure the safety of the property.

This handsome colonial structure is in Christopher Wren style, measures 66 by 34 feet, and has two stories and a basement. In the basement are a modern sorting shop and conditioning room for grading tobacco, $t w$, completely equipped photographic rooms, laboratories for chemistry, soils, and entomology, a work shop and a boiler room. The building is steam heated from an oil-burning furnace. On the first floor are a general office and offices for the staff, a plant pathology laboratory, a library and conference room. On the second floor is an auditorium for meetings of growers and space for four laboratories that will be finished when they are needed. A cupola over the roof furnishes shelter for weather instruments.

The old building was made possible by funds contributed by the tobacco growers' organization, The Connecticut Valley Tobacco Improvement Association. The new building is being constructed under supervision of the State Public Works Department, and paid for by joint contributions of the State and the Works Progress Administration. 


\section{Change \\ in \\ Staff}

In August, Dr. O. E. Street, Physiologist and Chemist since 1929, resigned to take a post with the U. S. Department of Agriculture in charge of tobacco investigations at Lancaster, Pennsylvaniá. During his 10 years here, Dr. Street made valuable contributions to our knowledge of tobacco culture, particularly on the processes of curing and fermentation, the leaching of plant nutrients from tobacco soils, and correlation of growth with absorption of nutrients. His departure to take a more responsible position is a distinct loss to this Station. Dr. Stuart LeCompte, Jr., has been appointed to take his place.

$\begin{array}{cl}\text { Direct Service } & \text { This branch of our work shows an increase every year. } \\ \text { to } & \text { Between four and five thousand samples of soil annu- } \\ \text { Growers } & \text { ally are brought to the Station for analyses as a basis } \\ \text { for fertilizer treatment. Most of them are from tobacco }\end{array}$ fields but each year a larger number comes from fields of other farm crops, vegetables, orchards, lawns and gardens, as the public becomes more convinced of the value of these analyses. The Station also receives several hundred samples of tobacco seed for germination tests and cleaning yearly. The number of these remains practically constant. Since the Substation is so near the center of the tobacco growing area, within a half-hour drive of most of the tobacco farms of the State, many growers consider it profitable to call occasionally for conference with members of the staff. Much time is spent in these conferences, but we believe it is a more effective means of giving information than the more usual public meetings. This has been supplemented during the year, however, by a few public gatherings of growers, by publication of bulletins and circulars, and by many farm visits. These last are essential if the staff is to keep in close touch with the problems of the industry.

The Hailstorm of August 4.

One of the few local hailstorms of the year centered on the Substation farm, August 4, after the tobacco was topped, causing a loss estimated at 50 percent of the crop. The tobacco was not blown over, however, and the principal damage consisted of scattered holes in the leaves. This did not prevent the collecting of the usual data on the experiments, despite the reduced commercial value of the crop. In the sorting shop the leaves were graded just as if there were no holes in them-eliminating, however, the two top grades, light and inedium wrappers. The data are probably not as reliable as they would be for an undamaged crop but since all plots suffered equally, comparison among them should reflect true differences.

\section{The European War and Potash for Tobacco}

The war situation in Europe has almost completely shut off our supply of sulfate of potash, the standard form of potash for tobacco mixtures. This has always been imported from Germany or France and very little is produced in this country, although facilities for adequate domestic production could be developed in a short time if foreign competition were eliminated. The same is true of nitrate of potash. America has large sources of muriate of potash but this is not suitable for tobacco. In a long series of experiments at the Tobacco Substation it was shown that there are two kinds of potash carriers that are superior to sulfate. The first of these is ground stems, a byproduct of nicotine extraction, more expensive 
to use than the sulfate but producing better tobacco. The second one is cottonhull ash, a byproduct of the cotton ginning industry in the South. Our results show that this also is superior to sulfate and the cost is about the same as for sulfate in normal times. Both of these are American products and there is an adequate supply for our needs.

\section{Fertilizer \\ Tests}

No detailed reports on fertilizer tests are included in this bulletin. Departure from our usual practice is necessitated by a reduction in the state printing budget. As it happens, none of the previously unreported tests are at a stage that calls for a full report at present. These experiments have been continued on the same scale as in previous years, and two new series have been added in 1939. One is a trial of sewage sludge from the Hartford Metropolitan Sewage Disposal Plant. The second is a test of placement of fertilizers in or very near the rows, instead of broadcasting.

Table 1. Distribution of Rainfall in Inches at the Tobacco Substation, Windosor, 1939

\begin{tabular}{|c|c|c|c|c|c|c|c|c|c|c|c|}
\hline \multicolumn{3}{|c|}{ May } & \multicolumn{3}{|c|}{ June } & \multicolumn{3}{|c|}{ July } & \multicolumn{3}{|c|}{ August } \\
\hline \multicolumn{12}{|c|}{ By 10-day Periods } \\
\hline $1-10$ & $11-20$ & $21-31$ & $1-10$ & $11-20$ & $21-30$ & $1-10$ & $11-20$ & $21-31$ & $1-10$ & $11-20$ & $21-31$ \\
\hline .07 & 0 & .88 & .94 & .82 & 2.61 & .59 & 1.64 & .33 & 2.43 & 1.06 & 2.13 \\
\hline \multicolumn{12}{|c|}{ By Months } \\
\hline \multicolumn{3}{|c|}{.95} & \multicolumn{3}{|c|}{4.37} & \multicolumn{3}{|c|}{2.56} & \multicolumn{3}{|c|}{5.62} \\
\hline \multicolumn{12}{|c|}{ A verage for Preceeding 17 Years } \\
\hline \multicolumn{3}{|c|}{348} & \multicolumn{3}{|c|}{3.72} & \multicolumn{3}{|c|}{3.69} & \multicolumn{3}{|c|}{4.28} \\
\hline
\end{tabular}

\section{Irrigation \\ Tests}

Tests on the influence of irrigation, with and without the addition of nitrate in the water, are conducted every year when the season is dry enough to warrant the use of water. A short, dry, hot period in July, 1939, furnished opportunity for one irrigation but rains came soon afterward and little if any advantage resulted.

Ammonification

$$
\text { of }
$$

\section{Fertilizers}

Although many investigations have been made on nitrification, very little has been done on ammonification of nitrogenous tobacco fertilizers, a process which precedes nitrification and which may explain some of the differences in behavior of fertilizers. Weekly tests of the soil on the "singlesource-of-nitrogen" plots for both ammonia and nitrates were begun with the season of 1939. They are giving interesting and significant results. It is planned to continue the program through several years to compare results under different seasonal conditions. This work may also be important in explaining injuries to young plants from certain fertilizers. 
Calcium

The supply of calciam in the soil seens to have an important effect on the quality and quantity of tobacco grown thereon. In these plots various quantities of calcium are applied without disturbing the soil reaction. The experiment has been going on for four years.

In the following pages will be found a nore complete discussion of some of the projects on which the staff has been engaged.

\section{TIME OF HARVESTING HAVANA SEED TOBACCO V. SUMMARY OF FIVE YEARS' TESTS}

THESE experiments, started with the purpose of determining how long tobacco should be left in the field after topping to give optimum results, was repeated in 1939 in the same location on Field $I$ as in the preceding years. Two strains of Havana Seed tobacco, the Brown strain and No. 211, were used and their position in the field was reversed each year. Beginning one week after the field was "topped clean", about 250 plants were harvested each week at seven-day intervals. The essential details of manipulation were the same as in the preceding years and need not be repeated here. Hail injury rendered careful sorting more difficult than usual and for this reason the grade indexes are probably not as reliable as for other years. The hail injury did not affect materially the weight of the tobacco, however, and therefore the acre yields should be relatively accurate.

Table 2. Time-of-harvesting Plots. Sorting Records; Crop of 1939

\begin{tabular}{|c|c|c|c|c|c|c|c|c|c|}
\hline \multirow{2}{*}{ Type } & \multirow{2}{*}{ Weeks after topping } & \multirow{2}{*}{ Acre yield } & \multicolumn{6}{|c|}{ Percentage of Grades } & \multirow{2}{*}{ Grade Index } \\
\hline & & & LS & SS & LD & DS & B & $\mathbf{F}$ & \\
\hline Brown & $\begin{array}{ll}1 & \text { week } \\
2 & \text { “، } \\
3 & \text { ، } \\
4 & \text { ، }\end{array}$ & $\begin{array}{l}1511 \\
1683 \\
1636 \\
1865\end{array}$ & $\begin{array}{l}31 \\
30 \\
33 \\
26\end{array}$ & $\begin{array}{r}12 \\
7 \\
9 \\
6\end{array}$ & $\begin{array}{l}38 \\
51 \\
44 \\
56\end{array}$ & $\begin{array}{l}6 \\
2 \\
2 \\
3\end{array}$ & $\begin{array}{l}\ldots \\
\ldots \\
\ldots\end{array}$ & $\begin{array}{r}13 \\
10 \\
12 \\
9\end{array}$ & $\begin{array}{l}.361 \\
.368 \\
.373 \\
.357\end{array}$ \\
\hline No. 211 & $\begin{array}{ll}1 & \text { week } \\
2 & \text { ، } \\
3 & \text { ، } \\
4 & \text { ، }\end{array}$ & $\begin{array}{l}1994 \\
2086 \\
2122 \\
2283\end{array}$ & $\begin{array}{l}30 \\
35 \\
32 \\
37\end{array}$ & $\begin{array}{l}8 \\
8 \\
6 \\
3\end{array}$ & $\begin{array}{l}53 \\
49 \\
56 \\
53\end{array}$ & $\begin{array}{l}1 \\
1 \\
1 \\
1\end{array}$ & $\begin{array}{l}\cdots \\
\cdots \\
\cdots\end{array}$ & $\begin{array}{l}8 \\
7 \\
5 \\
6\end{array}$ & $\begin{array}{l}.373 \\
.391 \\
.385 \\
.398\end{array}$ \\
\hline
\end{tabular}

The sorting results and acre yields for the year are shown in Table 2. With two minor exceptions, the figures show regular increases in weight and improvement in quality for each of the three weeks. During this period the Brown strain increased 354 pounds in weight and the No. 211 increased 289 pounds.

A summary of results obtained during the three years that these tests have been carried out on Field $I$ is presented in Table 3. The average yields are greatly reduced by the low yields of the abnormally wet season of 1938, but there is uniformly an increase in yield and improvement in grading with each additional week the crop stands in the field. 
Table 3. The of Harvesting Havana Seed Tobacco. Summary of Three Years' Results on Field I.

\begin{tabular}{|c|c|c|c|c|c|c|c|c|c|}
\hline \multirow[t]{2}{*}{ Type } & \multirow{2}{*}{$\begin{array}{l}\text { Weeks } \\
\text { after } \\
\text { topping }\end{array}$} & \multicolumn{4}{|c|}{ Acre Yield } & \multicolumn{4}{|c|}{ Grade Index } \\
\hline & & 1937 & 1938 & 1939 & Av. & 1937 & 1938 & 1939 & Av. \\
\hline Brown & $\begin{array}{l}1 \\
2 \\
3 \\
4\end{array}$ & $\begin{array}{l}1672 \\
1852 \\
1937 \\
1844\end{array}$ & $\begin{array}{r}1046 \\
977 \\
1046 \\
1343\end{array}$ & $\begin{array}{l}1511 \\
1683 \\
1636 \\
1865\end{array}$ & $\begin{array}{l}1413 \\
1503 \\
1540 \\
1684\end{array}$ & $\begin{array}{l}.347 \\
.385 \\
.369 \\
.102\end{array}$ & $\begin{array}{l}.253 \\
.241 \\
.248 \\
.300\end{array}$ & $\begin{array}{l}.361 \\
.368 \\
.373 \\
.357\end{array}$ & $\begin{array}{l}.320 \\
.331 \\
.330 \\
.353\end{array}$ \\
\hline No. 211 & $\begin{array}{l}1 \\
2 \\
3 \\
4\end{array}$ & $\begin{array}{l}2000 \\
2031 \\
2212 \\
2187\end{array}$ & $\begin{array}{l}1195 \\
1269 \\
1606 \\
1822\end{array}$ & $\begin{array}{l}1994 \\
2086 \\
2122 \\
2283\end{array}$ & $\begin{array}{l}1729 \\
1795 \\
1980 \\
2097\end{array}$ & $\begin{array}{l}.380 \\
.417 \\
.428 \\
.433\end{array}$ & $\begin{array}{l}.331 \\
.323 \\
.369 \\
.423\end{array}$ & $\begin{array}{l}.373 \\
.391 \\
.385 \\
.398\end{array}$ & $\begin{array}{l}.361 \\
.377 \\
.394 \\
.418\end{array}$ \\
\hline
\end{tabular}

Table 4. Time of Harvesting. Sonting Records on Crop of 1939. Total Percentage of Leaves of Different Lengths.

\begin{tabular}{|c|c|c|c|c|c|c|c|c|c|c|}
\hline \multirow[b]{2}{*}{ Type } & \multirow{2}{*}{$\begin{array}{c}\text { Weeks } \\
\text { after } \\
\text { topping }\end{array}$} & \multicolumn{8}{|c|}{ Percentage in Different Lengths } & \multirow{2}{*}{$\begin{array}{c}\text { Weighted } \\
\text { Av. leaf } \\
\text { length }\end{array}$} \\
\hline & & Fillers $+15^{\prime \prime}$ & $17^{\prime \prime}$ & $19^{\prime \prime}$ & $21^{\prime \prime}$ & $23^{\prime \prime}$ & $25^{\prime \prime}$ & $27^{\prime \prime}$ & $29^{\prime \prime}$ & \\
\hline Brown & $\begin{array}{l}1 \\
2 \\
3 \\
4\end{array}$ & $\begin{array}{l}17 \\
12 \\
14 \\
11\end{array}$ & $\begin{array}{r}13 \\
8 \\
8 \\
7\end{array}$ & $\begin{array}{l}21 \\
15 \\
16 \\
17\end{array}$ & $\begin{array}{l}29 \\
22 \\
21 \\
19\end{array}$ & $\begin{array}{l}19 \\
23 \\
25 \\
19\end{array}$ & $\begin{array}{l}1 \\
17 \\
15 \\
16\end{array}$ & $\begin{array}{r}3 \\
1 \\
11\end{array}$ & $\begin{array}{l}\ldots \\
\ldots \\
\ldots\end{array}$ & $\begin{array}{l}19.50 \\
20.98 \\
20.62 \\
21.40\end{array}$ \\
\hline No. 211 & $\begin{array}{l}1 \\
2 \\
3 \\
4\end{array}$ & $\begin{array}{r}10 \\
9 \\
6 \\
6\end{array}$ & $\begin{array}{l}6 \\
7 \\
4 \\
3\end{array}$ & $\begin{array}{r}13 \\
13 \\
10 \\
8\end{array}$ & $\begin{array}{l}21 \\
18 \\
17 \\
15\end{array}$ & $\begin{array}{l}22 \\
22 \\
22 \\
20\end{array}$ & $\begin{array}{l}20 \\
23 \\
26 \\
26\end{array}$ & $\begin{array}{r}6 \\
8 \\
13 \\
16\end{array}$ & $\begin{array}{l}1 \\
2 \\
6\end{array}$ & $\begin{array}{l}21.37 \\
21.76 \\
22.70 \\
23.24\end{array}$ \\
\hline
\end{tabular}

\section{Summary of Five Years' Tests}

These tests have now been carried out through five seasons on three fields of varying soil characters and supplemented by laboratory analyses. At the end of five years of variable seasons and soils we should now be in a position to summarize results and draw some general conclusions in answer to the questions which this set of experiments was designed to answer.

Every year the stalk grower must decide for himself when his tobacco is just right to harvest. There is no infallible rule or signal to tell him. He loses money if he cuts the crop too soon and likewise if he waits too long. Usually he claims that he harvests when the leaves are "ripe". But "ripe" is a relative term dependent on the conception of the individual grower. One says the leaf is ripe when the yellow mottle spots begin to show on the margin. Since this symptom is progressive from top to bottom, does he mean mottling of the top leaves, middle leaves or bottom leaves? And mottling varies greatly with the season, soil, fertilizer and water. Some years it comes very early, sometimes it hardly shows at all, especially on certain soils. The same may be said of the other commonly alleged symptoms of ripening, such as the down curving of the leaf margins, the stiffening of the web, development of a waxy feeling, cracking of the veins 
when bent between the fingers, cracking of the root when the stalk is pushed over, and the like. All of these signs show too much variation in degree and time of appearance, so the grower is prone to use them largely to support his guess as to what time would be most convenient for him to start cutting.

In the absence of definite criteria for fixing the date of harvesting, and influenced, moreover, by the fear of injury from hail storms, wind, insects and diseases, there has been a tendency for growers gradually to hasten the date of harvesting. The net result is that many cut their tobacco green with a consequent loss in both quality and yield.

On the other hand, there are growers who consider that the age of the plants, or length of development after certain operations, is a more reliable means of determining the right time of harvesting. They believe that this should have at least equal weight with the ripening symptoms mentioned above. It was in an effort to measure the influence of the time element and to determine the reliability of the time method that this series of tests was started.

First of all, it is necessary to have a definite point from which to count time. The date of setting the plants in the field is too remote and the rate of development too much influenced by external conditions to make this a reliable starting point. The date of the opening of the first blossoms, however, marks a definite stage in the plant's development and may be better used for this purpose. At this stage, when the first pink corollas of the flower head open, the top should be broken out, causing the plant to expend its force in enlarging the leaves instead of producing seed. All plants in a field, however, even if set on the same day, do not flower at exactly the same date. Some push ahead of the rest and some are slow. It is a common practice for growers first to remove the flower heads of early blooming plants, by a process called "budding". Then, after a few days, when the late blooming plants have begun to flower, they "top clean", i.e., break off the tops of all plants, including those previously budded, at a uniform height, leaving an average of 13 to 16 leaves per plant according to individual judgment or custom. It is this operation of clean topping that we have used as the starting point in the experiments at the Station farm.

In these, a field of uniform growth and appearance, with all the rows set the same day and having received the same fertilizer and cultural care, is used. One week after clean topping, three or four rows (about 300 plants) are harvested. Seven days later, after discarding a border row, three or four more rows are harvested. This is repeated at the end of the third week. On one field it was also repeated for the fourth week. All the tobacco is hung for curing in the same shed on the same tier of poles, and after curing, is stripped all at one time and graded in the Station sorting shop.

All the tests were on typical tobacco soils of the Merrimac series, but on three different fields which exhibit different capacities to retain moisture and food elements. The first tests were on Field V, a dry, "leachy" soil, where sand predominates, the water and plant food leach through quickly, and the crop is soon affected by dry weather. Field I, where the latest tests were made, does not leach badly, suffers during a wet year, but retains moisture sufficiently, even during a very dry year, to produce a good 
crop. Field XI, where the 1936 tests were located, is about midway between the other two in its soil characteristics and almost always produces a heavy yield of good tobacco. The conclusions from these tests should thus be applicable to a wide range of fields throughout the Connecticut Valley.

Strains of tobacco used. In all of the tests in this series Havana Seed tobacco of two different strains was used. The first was the so-called Brown strain, a seed that has been planted for years at the Station and which was originally obtained from the late Stanton F. Brown. Several seasons of comparative testing here showed it to be one of the best of the strains of long standing in this section. After the first year, another strain, No. 211, was added to the tests. This is one of the best of the recently developed strains for resistance to black rootrot. Since it yields more heavily than the Brown strain and appears to reach maturity more slowly, it seemed possible that it should be left longer in the field. It was to settle this point that No. 211 was included in the tests after the first year.

The weights and percentages of grades have been published annually in our previous reports.* A summary of results obtained from all the tests of the five years is presented in Table 5.

Table 5. Time of Harvesting Havana Seed Tobacco. Summary Table of All Experiments for Five Years. Yield and Grade Index.

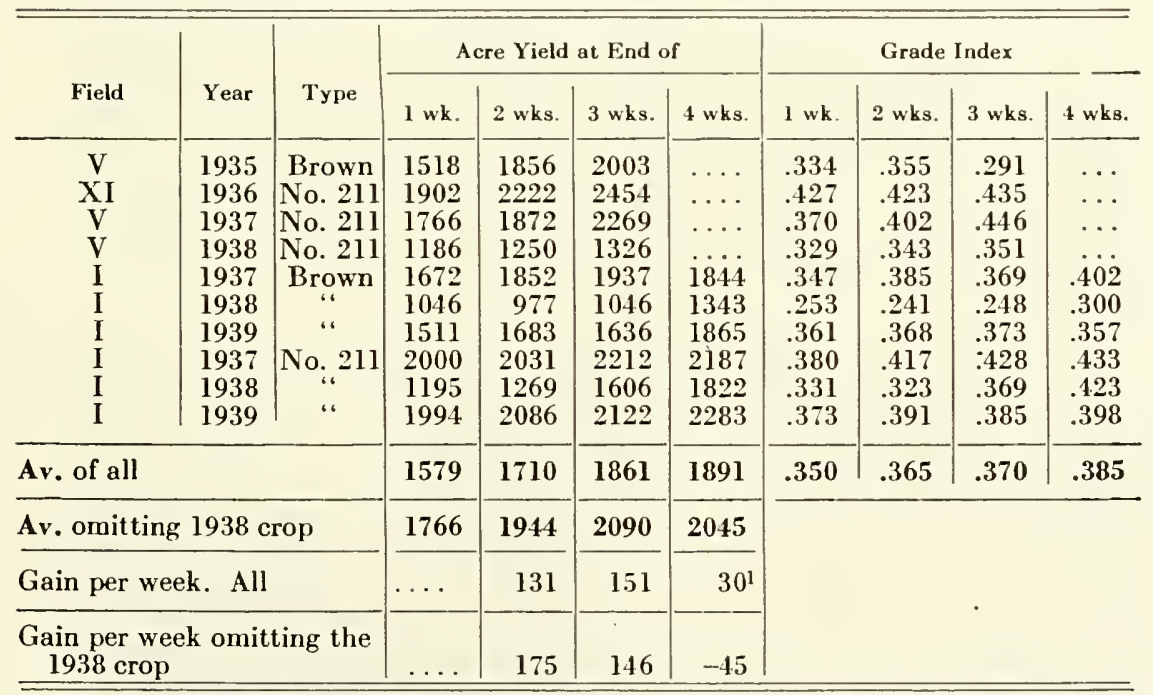

${ }^{1}$ Using only results on Field 1 , would be 134 .

Gain in weight. This table shows an average gain in weight of 131 pounds between the seventh and fourteenth days after topping. If we omit from the calculation the low yields of the abnormally wet year of 1938, the gain is 175 pounds for this week. Between the fourteenth and

* Conn. Exp. Sta. Bul. 386:585; 391:73; 410:368; $422: 20$. 
twenty-first days, the gain was 151 pounds (140 without the $1938 \mathrm{crop}$ ). For calculating the gain during the fourth week (twenty-first to twentyeighth days) we can use only the results on the Field I tests since in the first tests on the other two fields none of the tobacco was left to the end of the fourth week. Averaging the results from this field, there was a net gain of 134 pounds for the fourth week. During one of the years, 1937, however, there was an actual loss of weight during this fourth week.

In round numbers we may conclude then that Havana Seed tobacco will add 150 pounds an acre per week during the second and the third weeks after topping and may do nearly as well the fourth week depending on the season. During a very dry season the lower leaves may die off if the tobacco is left too long in the field, which may result in a loss of weight during the fourth week. On the other hand, during a wet year there may be a shortage of nitrogen in the plant so that the leaves cannot increase in size. At the same time nitrogen and potash and other elements may be translocated to the suckers from the leaves, thus causing a loss in dry weight.

Improvement in the grading. In Table 5 it will be noted that almost uniformly each week has improved the grade index ${ }^{1}$ in every set of tests.

The improvement is well shown by the averages of $.350, .365, .370$ and .385 for the successive weeks. This improvement in grading is due to increased percentage of higher priced leaves and decreased percentage of low priced leaves with each week. The progressive increase in length of all leaves (discussed below) naturally results in a smaller percentage of the low priced short grades, i.e., fillers, short darks and short seconds. These shift to the long seconds and long darks while some of the latter grades shift to light and medium wrappers. There is also an improvement in the quality of the tobacco which is not indicated by the grade index. The more mature leaves have the appearance of ripe tobacco which is desired by the manufacturer.

Increase in size of leaf. In the annual reports on this series of experiments, it has been shown that during the weeks following topping there has been a weekly increase in length of the leaves. The sizing of the leaves at time of sorting allows us to calculate the percentage of leaves in each length (intervals of 2 inches) and from this, the average length of the leaves at the end of each week. A summary of calculations which were made on one or more of the tests during each of the five years is presented in Table 6. An average of all these tests shows that there was an increase of 1.06 inches in length of leaf between the seventlı and fourteenth days after topping, .63 inch between the fourteenth and twenty-first days and .26 inch between the twenty-first and twenty-eighth days. This shows a

\footnotetext{
1 Grade index is a figure which represents the relative value of a lot of tobacco oomputed on the percentage weight of each grade of leaves in the lot and the relative values of these grades. Assuming that the light wrapper is the perfect leaf of Havana Seed tobacco, we assign to it a value of 100 . The other grades are assigned values of the same proportion to 100 as their market value was to the price of the light wrapper when this system was established. Thus medium wrappers have a value of 60 ; long seconds (19 inches or more) are 60 ; short seconds (15 inches and 17 inches) are 30; long darks are 30; dark stemming (short darks of 15 inches and 17 inches) are 20 ; fillers and brokes are 10 . It is true that the values of these grades have fluctuated considerably during the 15 years that we have used this system of comparing lots of tobacco, but in order to be able to average results over a period of years it seems advisable to retain the aame system for the present. To obtain the grade iudex figure, the percentage of each grade in a lot of tobacco is multiplied by the relative values noted above and then the products are added.
} 
decreasing rate of "stretch" as the leaves become older. Previous investigations have shown that the greatest increase in length is in the uppermost leaves, decreasing downward until there is very little, if any, stretch in the lowermost leaves at this time. All leaves are included, however, in the averages given here.

But the leaves increase in width as well as length. A long series of exact measurements in connection with other experiments showed the shape of Havana Seed leaves of these two strains is remarkably constant and maintains a ratio of length to width of 2 to 1 . Every increase of an inch in length, therefore, means half an inch in width. The area of the leaf may be roughly calculated by considering each as an ellipse with a long axis of twice the short axis. Calculating the areas in this way, as shown at the bottom of Table 6 , there was an increase in average leaf surface of about 20 percent in three weeks, half of which was added between the seventh and fourteenth days.

Table 6. Increase in Size of Leaves After Topping. Summary of Five Years Tests

\begin{tabular}{|c|c|c|c|c|c|c|}
\hline \multirow[b]{2}{*}{ Year } & \multirow[b]{2}{*}{ Field } & \multirow[b]{2}{*}{ Type } & \multicolumn{4}{|c|}{ Average Leaf Length (inches) } \\
\hline & & & I wk. & 2 wks. & 3 wks. & 4 wks. \\
\hline $\begin{array}{c}1935 \\
1936 \\
1937 \\
\text { Av. for Field }\end{array}$ & $\begin{array}{c}\mathrm{V} \\
\mathrm{X} I \\
\mathrm{~V} \& \mathrm{XI}\end{array}$ & $\begin{array}{l}\text { Brown } \\
\text { No. } 211 \\
\text { No. } 211\end{array}$ & $\begin{array}{l}19.44 \\
21.46 \\
18.90 \\
19.93\end{array}$ & $\begin{array}{l}20.75 \\
22.86 \\
19.80 \\
21.13\end{array}$ & $\begin{array}{l}21.86 \\
23.25 \\
20.64 \\
21.92\end{array}$ & $\begin{array}{l}\cdots \\
\cdots \\
\cdots \\
\cdots\end{array}$ \\
\hline $\begin{array}{l}1937 \\
1937 \\
1938 \\
1939 \\
1939\end{array}$ & $\begin{array}{l}\text { I } \\
\text { I } \\
\text { I } \\
\text { I } \\
\text { I }\end{array}$ & $\begin{array}{l}\text { Brown } \\
\text { No. } 211 \\
\text { No. } 211 \\
\text { No. } 211 \\
\text { Brown }\end{array}$ & $\begin{array}{l}19.06 \\
20.14 \\
18.38 \\
21.37 \\
19.50\end{array}$ & $\begin{array}{r}20.90 \\
21.04 \\
\cdot 18.66 \\
21.76 \\
20.98\end{array}$ & $\begin{array}{l}21.00 \\
21.58 \\
20.14 \\
22.70 \\
20.62\end{array}$ & $\begin{array}{l}21.42 \\
21.34 \\
21.26 \\
23.24 \\
21.40\end{array}$ \\
\hline \multicolumn{3}{|l|}{ Av. for Field I } & 19.69 & 20.67 & 21.21 & 21.73 \\
\hline \multicolumn{3}{|c|}{ Av. for all fields } & 19.78 & 20.84 & 21.47 & 21.73 \\
\hline \multicolumn{3}{|c|}{ Weekly gain in leaf length (inches) } & $\ldots$ & 1.06 & .63 & .26 \\
\hline \multicolumn{3}{|c|}{ Av. area of each leaf (sq. inches) } & 153.86 & 170.62 & 181.26 & 185.84 \\
\hline \multicolumn{3}{|c|}{$\begin{array}{l}\text { Total gain in percentage of leaf area at } \\
\text { end of each week }\end{array}$} & $\ldots$ & $10.9 \%$ & $17.8 \%$ & $20.8 \%$ \\
\hline \multicolumn{3}{|c|}{$\begin{array}{l}\text { Total gain in percentage of weight of } \\
\text { leaves at end of each week }\end{array}$} & & $9.7 \%$ & $19.7 \%$ & $18 \%$ \\
\hline
\end{tabular}

The last line of this table shows the percentage of increase in the weight of the crop of leaves during these same weeks from the same plots. Comparing this with the line above, it is apparent that the percentage increase in weight at each stage of harvesting is about the same as the increase in leaf area. The correlation, at least, is about as close as could be expected with the rather rough method of calculation used. The increase in weight of the crop then seems to be due almost all, if not entirely, to increased 
leaf surface. In a previous report (Bul. 386, p. 587) it was suggested that a part of the increase in weight might be due to increased deposition of salts in the leaf. Chemical analysis showed, however, that there was no increase in total ash, calcium, potash or magnesia as calculated on the percentage dry substance of the leaf. It has also been suggested that the increase in weight is due to increase in thickness of the leaves. It is difficult to make accurate measurements of leaf thickness and no such have been attempted on these. In handling the leaves, however, one gets the impression that the earlier harvested leaves are much thinner. There is no increase in the actual number of cells in the leaf during this period but it is possible that the existing cells may stretch in a direction to produce thicker leaves and the cell walls become thicker and more rigid at the expense of their protoplasmic content. Such a development might cause the leaf to feel thicker without actually adding to its weight.

Comparison of the two strains of Havana Seed tobacco. The history of the two strains of Havana Seed tobacco used in these tests-the Brown strain and the No. 211 resistant strain-has been explained previously.

Table 7. Comparison of Brown Strain with Havana Seed No. 211 . Average Yields and Grade Indexes for Crops of 1937, 1938 and 1939

\begin{tabular}{l|c|c|c|c|c|c|c|c}
\hline \multirow{2}{*}{ Type } & \multicolumn{4}{c|}{ Acre Yield } & \multicolumn{4}{c}{ Grade Index } \\
\cline { 2 - 8 } & 1 wk. & 2 wks. & 3 wks. & 4 wks. & 1 wk. & 2 wks. & 3 wks. & 4 wks. \\
\hline Brown & 1410 & 1504 & 1540 & 1684 & .320 & .331 & .330 & .353 \\
\hline No 211 & 1730 & 1795 & 1980 & 2097 & .361 & .377 & .394 & .418 \\
\hline $\begin{array}{l}\text { Increase in favor } \\
\text { of No. 211 }\end{array}$ & 320 & 291 & 440 & 413 & .041 & .046 & .064 & .065 \\
\hline \hline
\end{tabular}

The yield figures given in Table 5 show that the No. 211 strain uniformly produces more poundage than the other, on one field reaching a high of 2,454 pounds to the acre. In the tests of the years 1937, 1938 and 1939 on Field I, they were grown side by side on the same soil and with identical fertilizer and cultural treatment, and we have here an opportunity to obtain accurate measurements of the two. The acre yields and grade indexes are shown in Table 7. In this table it will be seen that every comparison is in favor of the No. 211 strain. At the end of the fourth week the yield on the No. 211 strain was 413 pounds to the acre higher than on the Brown strain. The grade index was also correspondingly better. There was nothing in these tests to indicate that one of the two strains should be harvested sooner than the other; both were improved by leaving them in the field until the fourth week after harvesting.

It has been shown by analyses reported in a previous bulletin (Bul. $\mathbf{4 1 0}$, p. 372) that even when grown under identical conditions and treatment there are chemical differences between these two strains of tobacco; that is, from the same soil, one is able to absorb a greater amount of a chemical element than the other. Thus No. 211 leaves have a higher percentage of 
potash and nitrogen than the Brown strain, while the reverse is true with respect to calcium. Probably more complete analyses would show other chemical differences any of which might have important bearings on the differential characters of these two strains. This field of chemical research needs further exploration.

The No. 211 strain is highly resistant to black rootrot and may be grown on soils which have been heavily limed. In addition, it shows decided resistance to attack of flea beetles and less pronounced but still distinct resistance to thrips.

Effect of time of harvesting on the rate of cure. Every year it is very noticeable that the tobacco from the early harvested plots cures most slowly. The tobacco harvested the third and fourth weeks is completely cured before that cut two weeks earlier. The riper the tobacco when it is harvested, the more rapid the cure. This has a distinct advantage in that it reduces the time during which the leaves are exposed to the danger of pole rot and during which it is necessary to watch and manipulate the sheds.

Conclusions. These experiments have now been continued for five years on three different soils during varying seasons. In view of the consistent results obtained under the different conditions we believe that we can now answer the questions for which answers were sought:

1. Havana Seed tobacco should be allowed to remain in the field at least three and often four weeks after topping before it is harvested. Exceptions to this general rule may be necessitated by excessive leaching of fertilizer on sandy soils or by extreme drouths which cause premature "firing" of the bottom leaves.

2. The weight of the crop increases at a rate of about 150 pounds per week during the second and third weeks after topping, with a less pronounced gain during the fourth week.

3. The grading also improves during each successive week.

4. The increase in weight is due largely to increase in size (surface) of the leaves during these weeks.

5. Late harvesting accelerates the speed of curing and shortens the period of danger from shed troubles. It also gives it the characteristics of "ripeness" which are favored by dealers and manufacturers.

\section{VARIATION IN CHEMICAL COMPOSITION OF CURED TOBACCO LEAVES ACCORDING TO THEIR POSITION ON THE STALK}

\section{H. R. I'Anmer ${ }^{1}$, O. E. Street ${ }^{2}$ and P. J. Anderson}

THE position of the leaf on the stalk affects to a marked degree its physical characteristics such as color, thickness, shape, elasticity, "gumminess", etc. The taste and aroma are also affected. These differences caused by leaf position are the bases for the various grades into which tobacco is assorted and they determine the suitability of the leaves for different brands of cigars. Moreover, such differences necessitate different methods of handling, such as fermenting and aging.

\footnotetext{
1 Director of Research for the American Tobacco Company.

2 Formerly Physiologist of the Connecticut Tobacco Substation, now Agronomist in charge of Tobacco Research for the U. S. D. A. at Lancaster, Pennsylvania.
} 
Not only are there physical differences but, more important, there are chemical differences which are undoubtedly responsible for variations in taste, aroma, combustibility and other commercial characteristics.

A more exact knowledge of the extent and nature of such chemical variation would not only increase our ability to explain the commercial differences mentioned but might be the basis of changes in treatment for improvement of the grades. The object of the investigation discussed here was to measure accurately leaf by leaf the progressive increase or decrease of some of the elements and compounds which it is believed have important bearings on the quality of Havana Seed tobacco. It is planned to extend this investigation to a wider range of chemical constituents as time and opportunity present themselves.

A prelininary article based on analyses of the crop of 1936 was published in our report for 1938 (Conn. Agr. Exp. Sta. Bul. 422: 22-26). That article discussed only the elements potassium, magnesium, calcium and total nitrogen and represented a crop grown in a relatively dry year. In the present investigation tobacco from the crop of 1938, a season of excessive rain, was analyzed. This tobacco was grown on Merrimac sandy loam (Field I) and 3,350 pounds of a good tobacco fertilizer of the following formula was applied.

$\begin{array}{lc}\text { Cottonseed meal } & 1500 \text { pounds } \\ \text { Urea } & 150 \\ \text { Nitrate of potash } & 200 \\ \text { Soybean oil meal } & 500\end{array}$

This formula furnished 220 pounds of nitrogen, 100 pounds of phosphoric acid, 220 pounds of potash, 300 pounds of lime $(\mathrm{CaO})$ and 90 pounds of magnesia (MgO). On account of excessive rains, extra applications of nitrogen were applied, one of 60 pounds on June 30 and another of 25 pounds on July 13. The tobacco was harvested on August 19, three weeks after topping. Just as in all wet years, the yield was much reduced; 1606 pounds to the acre for the No. 211 strain, and 1046 for the Brown strain. Identical analyses were made on both of these strains. Brown represents a standard strain which has been grown here for many years, while the No. 211 is one of the rootrot resistant strains which we have been testing here for the last six years. Both were grown side by side in the same field and with the same treatment throughout.

After the tobacco was cured in the shed and at the time of stripping, 36 representative plants were selected from each strain. All the first leaves of each strain were tied in one "hand", all the second leaves in one "hand", etc., so that we had finally one "hand" of leaves representing each of the sixteen leaf positions on the stalk. After removing the midribs, the blades of the leaf were thoroughly air dried and ground to a powder for analyses. Determinations of total ash, potash, magnesia and lime were made by the Analytical Chemistry Department at the Main Station, New Haven. All other determinations were made in the laboratory of the American Tobacco Company at Richmond, Virginia.

The complete analyses are shown in Table 8.

Total ash. The average total ash of all leaves was $\mathbf{2 4 . 7 2}$ percent for No. 211 and 22.90 percent for Brown. The unusually high ash in the first 


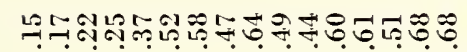

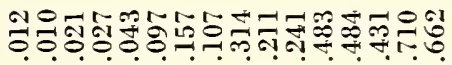

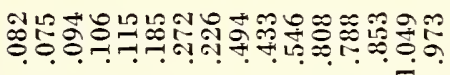

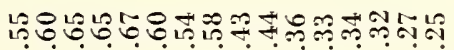

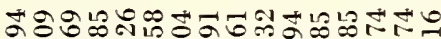

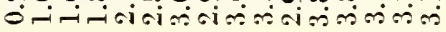

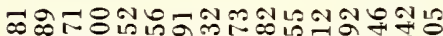

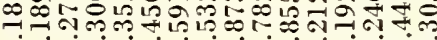

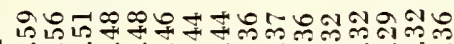

灵

nunounoonon

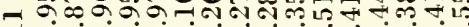

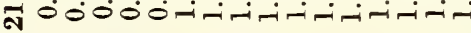
$\dot{\mathrm{z}}$

8 8

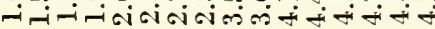

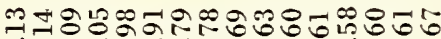
ini-io00000000000

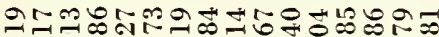

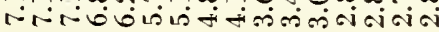

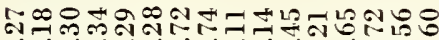

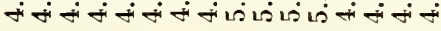

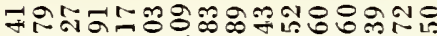
ต่อ

ஜังニコロ ดे

-

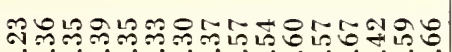

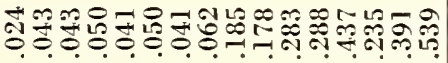

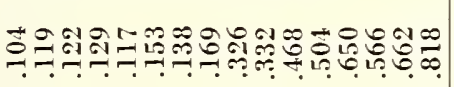

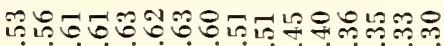

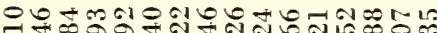
- - - -

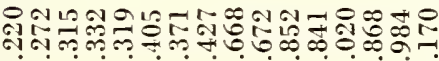
Q 苞

பீ

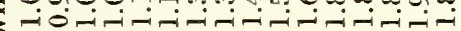

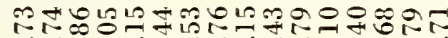

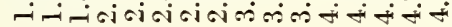

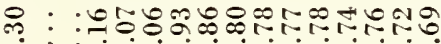

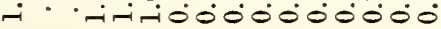

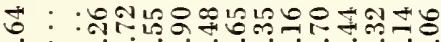

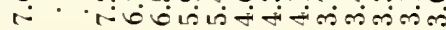

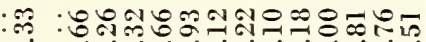

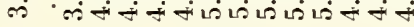

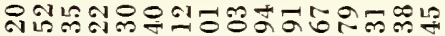

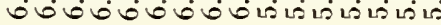

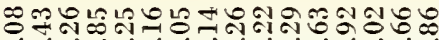

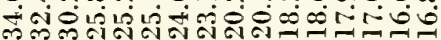

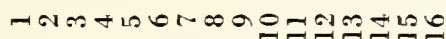


two or three leaves is probably influenced by adhering small particles_of sand that could not be entirely removed from the leaves and would be more pronounced in a year such as 1938 , with frequent, splashing rains. But

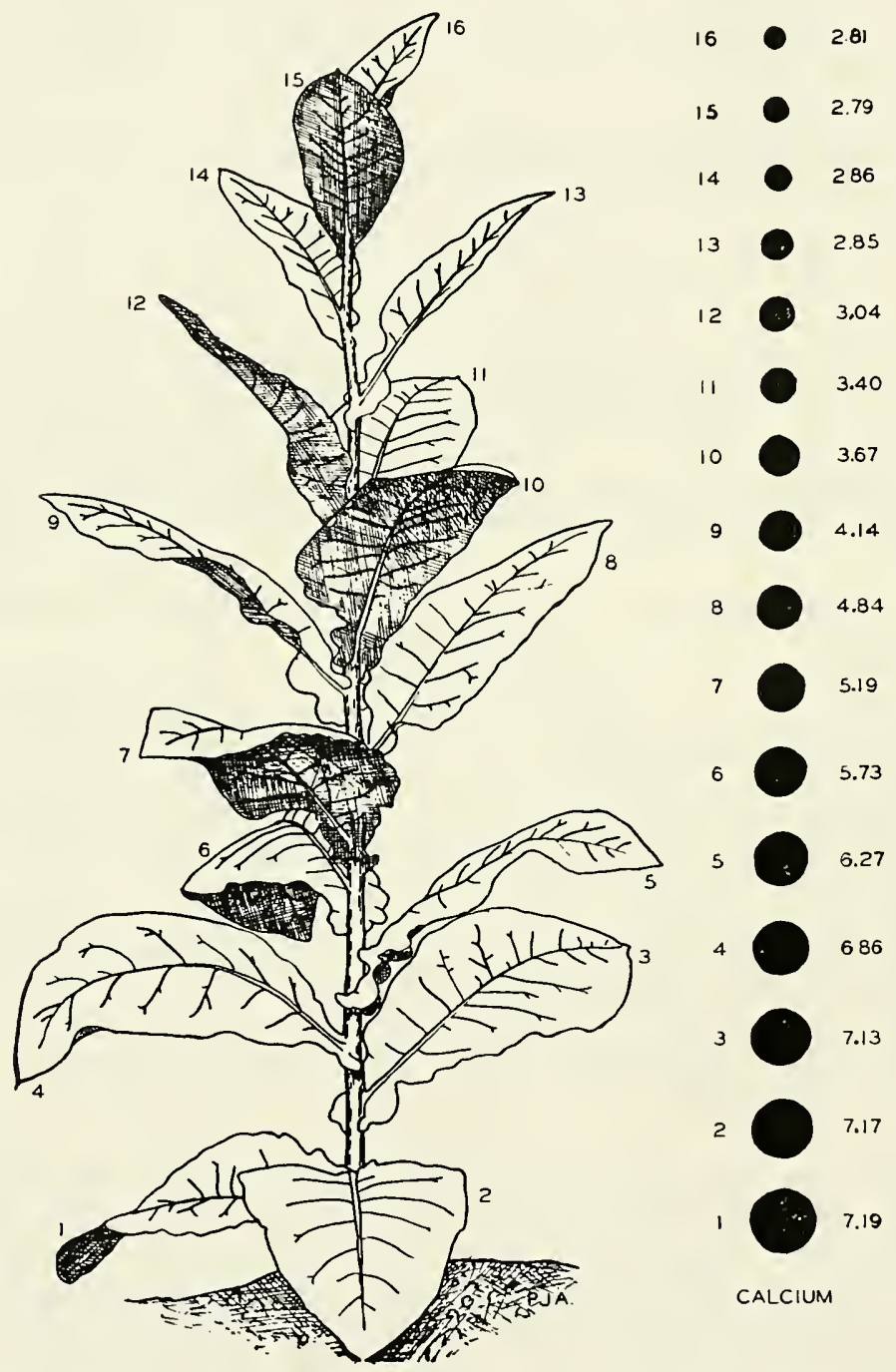

Figure 3. Distribution of calcium in the leaves. Diameters of black balls show relative percentages of $\mathrm{CaO}$ in leaves. (In this and the following figures, a Cuban Shade plant is substituted for Havana Seed because the large size and close setting of leaves of the latter obscure their position on the stalk.)

even after making allowances for the sand, the ash content of the lower leaves is about twice as great as that of the top leaf and there is a regular rate of decrease as we go up the stalk. The larger content of calcium and 
magnesia in the bottom leaves could account for a considerable part of the differences in total ash. The greater quantity of ash in the lower leaves was noted by Jenkins in his analyses of the crop of 1896 (Rept. of Conn. Agr. Exp. Station for 1896: 322-333) and by Anderson and Bailey in analyses of the crops of 1925 and 1926 (Tobacco Station Bul. 10:41). Comparing all the analyses that have been published, we may say in round numbers that Connecticut Valley Havana Seed tobacco contains about 25 percent ash. The averages for 1938 are slightly lower, however.

Degree of acidity. There is a general increase in acidity of the leaves from bottom to top of the sialk; the range shown here being $6.79 \mathrm{pH}$ to $5.31 \mathrm{pH}$. Whether the degree of acidity per se has any effect on the taste or aroma or other quality characteristics is not clear.

Potash. In both the strains, potash increases regularly up to the tenth to twelfth leaves and then declines regularly to the top. This unusual curve is difficult to explain. Previous analyses of crops, for 1896, 1925 and 1936, uniformly show more potash in the bottom leaves while this year the bottom leaves are lowest in potash. We know that during the excessive rains of 1938 , considerable available potash was leached from the soil and under these conditions the plant was probably forced to reutilize the store of potash from the lower, more mature leaves, by translocating it to the growing leaves higher up. The average percentage of potash for all leaves was 4.47 for the Brown strain and 4.66 for the No. 211 strain. The average for a similar leaf-by-leaf analysis made on the crop of 1936 on the same soil and fertilized in the same way was 3.1 percent $\mathrm{K}_{2} \mathrm{O}$. The lower figure for 1936 is due to the dry growing season of that year. Wet seasons invariably show a higher potash content of the leaves than dry seasons. This is undoubtedly one of the reasons why tobacco from a wet season crop invariably has a longer fire holding capacity.

Calcium. The percentage of calcium in the bottom leaves is about 2.5 times as high as in the top leaves and the rate of decrease is quite regular from bottom to top (Fig. 3). The average of all leaves is 4.75 for the No. 211 strain and 5.29 for the Brown strain. This agrees with previous analyses (Bul. 410: 372) which showed that the Brown strain naturally is higher in calcium than the No. 211 strain. A similar analysis for the No. 211 strain in the dry year of 1936 gave an average of 6.77 percent $\mathrm{CaO}$, or 42 percent more than the wet year crop of 1938. This is further confirmation of our previous observation that the percentage of calcium is higher during a dry year and thus the reverse of the behavior of potash. This difference is probably due to greater leaching of calcium - much more than the leaching of potash - from the soil during a wet year. A low concentration of calcium in the soil water results naturally in a reduced absorption of calcium and this is further accentuated by the relatively greater abundance of potash which exerts an antagonistic pressure.

Magnesia. In both strains, the magnesia is highest in the lower leaves and decreases regularly to the top, being about twice as high in the lower as in the top leaves (Fig. 4). The distribution of magnesia follows the same trend as that of calcium. The higher percentage of magnesia and calcium in the lower leaves is responsible for the whiter ash which results from combustion of these leaves as compared with the upper leaves. 
In the dry year of 1936, the percentage of magnesia was twice as great in the respective leaves as it was in 1938 , but the trend followed the same course.

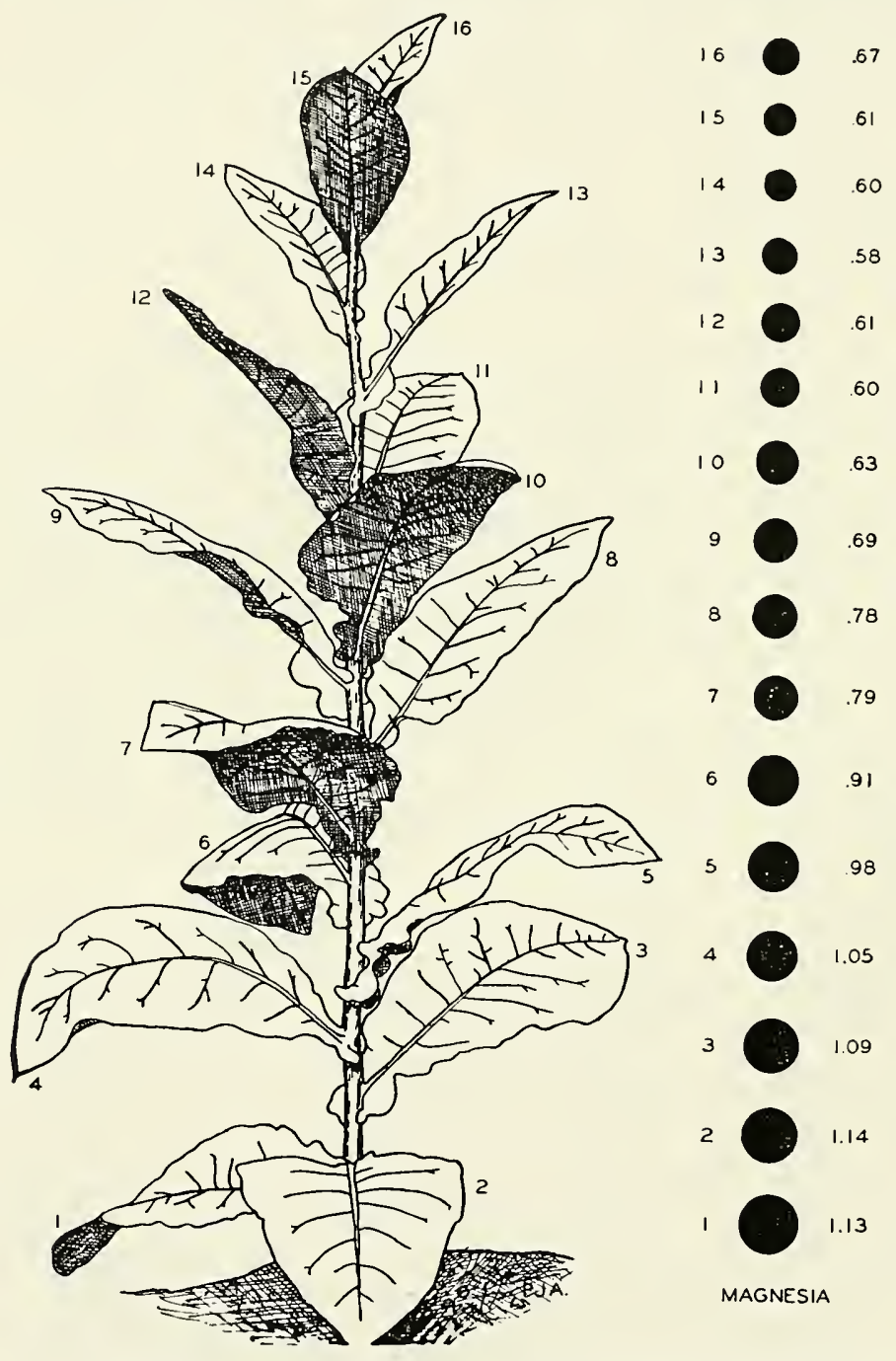

Figure 4. Distribution of magnesia in the leaves. Diameters of black balls show relative percentages of $\mathrm{MgO}$ in leaves.

Total nitrogen. In contrast to the mineral bases, the nitrogen content is lowest in the bottom leaves and increases regularly toward the top of the plant (Fig. 5). It reaches its peak in the fourteenth or fifteenth leaf and then declines in the ultimate leaf, a behavior which was duplicated in the crop of 1936. However, the average total nitrogen content of the No. 
211 strain of that year was higher by 7 percent than the 1938 crop, the difference being especially pronounced from the fifth leaf upward. This supports the preponderant evidence that total nitrogen, a factor closely related to strength of smoke, is highest in seasons of low rainfall. There is about three times as much nitrogen in the top leaves as in the bottom. All of the different compounds of nitrogen which were determined show this same trend of increasing toward the top of the plant.

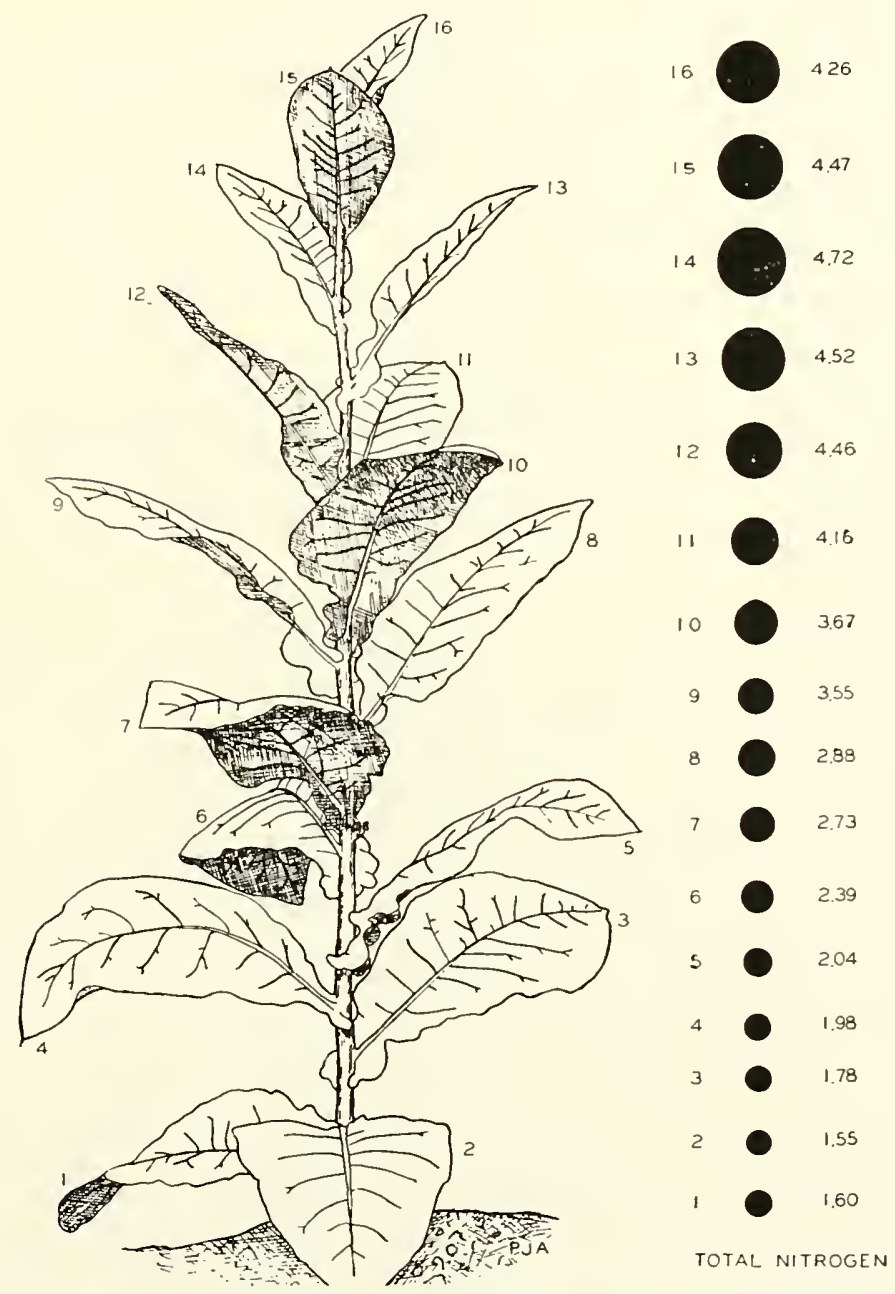

Figure 5. Distribution of total nitrogen in the leaves. Diameters of black balls show relative percentages of total nitrogen in leaves.

Protein nitrogen does not increase so rapidly as total nitrogen. About 60 percent of the nitrogen in the bottom leaves is in the form of proteins 
while only about 36 percent in the top leaves is in that form. The relatively more uniform distribution of this fraction is consistent with its insoluble nature.

Total volatile bases. This fraction comprises nicotine, ammonia and other volatile nitrogenous substances and is, perhaps more than the value for total nitrogen, a measure of smoking strength. This value increases tremendously from the bottom to the top of the plant, the most rapid increase being between the fifth and twelfth leaves.

Nicotine is highest in the upper half of the plant. It reaches a maximum in the eleventh leaf of the Brown strain and the twelfth and thirteenth leaves of the No. 211 strain. (Fig. 6).

Ratio of nicotine to total volatile bases is highest in the lower half of the plant, reaching a maximum in the fifth leaf of each strain and decreasing very regularly thereafter. While nicotine is low in the bottom leaves, it represents a larger proportion of total volatile bases than it does higher in the plant.

Total volatile bases minus nicotine and ratio of ammonia to total volatile bases minus nicotine are both considered in their relation to ammonia. The ratio indicates the relative abundance of ammonia in the volatile group. Where the ratio is low, a large proportion of the total volatile bases exists in an undetermined form. This condition prevails in the lower leaves, but the ratio increases sharply from the bottom to the top of the plant.

Ammonia shows the greatest range with respect to leaf position of any constituents determined. Very low in the bottom leaves, it manifests a pronounced and regular increase from bottom to top of the plant. The other volatile basic substances also show an increase with elevation of stalk position, but not to the same degree. This is apparent from the values for ratio of ammonia to total volatile bases minus nicotine which also show a marked increase from the bottom of the plant to the top. The senescence of the lower leaves is apt to be correlated with appearance of the nitrogen in more stable forms. The effect on smoking quality of the relatively large amounts of ammonia in the upper leaves is commonly recognized as a "stronger" smoke. Compared with the other constituents of the cigar, however, even the upper leaves of this crop are not high in ammonia. In particular it is lower than other binder types, such as Wisconsin, which may average above 1 percent (unpublished data).

A comparison of two strains of Havana Seed tobacco. The analyses presented in Table 8 show that very similar varieties of the same type of tobacco grown side by side and with equal opportunity to absorb food elements do not necessarily deposit in their leaves equal percentages of the various elements. Thus the Brown variety contains more calcium and magnesia, while the No. 211 variety has more potash. The percentage of nitrogen is about the same in both strains this year but was higher in the No. 211 strain in 1937 (Bul. 410: 372). When we compare the nitrogen fractions, however, we find that although the total nitrogen is about the same in both, the protein nitrogen is higher in the Brown strain, but the nicotine and ammonia fractions are ligher in the No. 211 strain. Such differences in chemical composition cannot but have an influence on taste, 
aroma and combustibility of the tobacco. Correlations between the quality factors and chemical composition have not been as thoroughly determined as could be desired but certainly offer a fertile field for further chemical research. This also points to the possibilities of improvement by selection among strains of a type or variety of tobacco.

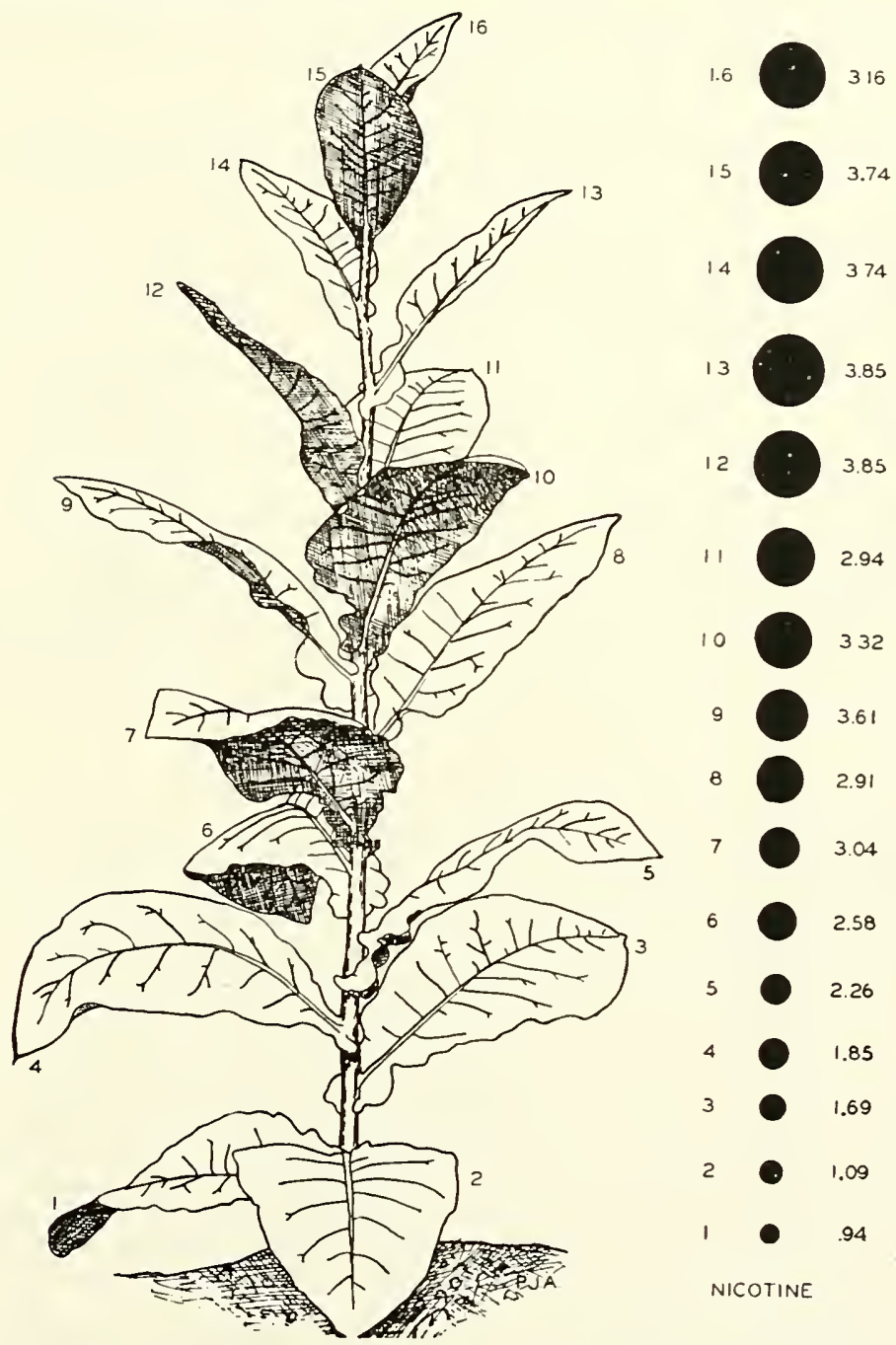

Figure 6. Distribution of nicotine in the leaves. Diameters of black balls show relative percentages of nicotine in leaves.

Summary. Using two strains of Havana Seed tobacco, leaf-by-leaf analyses for total ash, potash, calcium, magnesium, total nitrogen, protein nitrogen, volatile bases, nicotine and ammonia were made to determine variation in percentage of these components as influenced by leaf position. 
Total ash decreases from bottom to top, being about twice as abundant in the lower as in the top leaf. The average amount of ash in Connecticut tobacco is about 25 percent.

The leaves become more acid from bottom to top.

Potash percentage is highest in the ninth to twelfth leaves. Previous analyses had shown it to be higher in the bottom leaves. The trend is not so marked as for the other mineral bases.

Calcium is highest in the lower leaves and diminishes regularly upwards, so that it is two to three times as high in the bottom as in the top leaf.

Magnesia shows the same trend as calcium and is about twice as high in the lower as in the top leaf. However, the ash figures on the lower leaves may be influenced by the presence of sand.

Total nitrogen is highest in the top leaves and decreases regularly to the bottom where it is only about one-third as high as in the top.

Protein nitrogen shows the same trend as total nitrogen but the difference between top and bottom is not so great as for total nitrogen.

Total volatile bases increase rapidly from bottom to top.

Nicotine is more than three times as high in the top leaves.

Ammonia is 25 to 60 times as high in the top as in the bottom leaves.

\section{REPORT ON INSECT INVESTIGATIONS FOR THE 1939 SEASON}

A. W. Morrill, Jr., and D. S. Lacroix ${ }^{1}$

THE coöperative investigations on the control of the insect pests of tobacco in the Connecticut River Valley which have been carried on since 1936 by the Connecticut Agricultural Experiment Station and the Bureau of Entomology and Plant Quarantine of the United States Department of Agriculture ${ }^{2}$ were continued during the season of 1939.

In 1938, tests of combination dust mixtures and sprays for the control of the potato flea beetle, Epitrix cucumeris Harr., and the tobacco thrips, Frankliniella fusca Hinds, were made in an effort to obtain a simultaneous control of both insects. These were arranged in replicated plots in a Latin square and were repeated during 1939. Randomized block experiments on naphthalene as a soil fumigant for the control of wireworms, chiefly Limonius agonus Say, were also conducted. In addition, general field surveys and observations of the insect condition in the Connecticut River Valley were made during the season.

The treatments tested in an attempt to determine a single control measure for both the potato flea beetle and the tobacco thrips were as follows:

1. A cubé mixture containing 1 percent of rotenone; sterilized tobacco dust used as the diluent.

1 Burean of Entomology and Plant Quarantine, U. S. D. A. and Conn. Agr. Exp. Sta., respectively.

2 Morrill, A. W., Jr., and D. S. Lacroix. Experiments on Control of Tobacco Insects in 1936. Conn. Agr. Expt. Sta. Bui. 39I: 84-98. 1937. 
2. A cubé mixture containing 1 percent of rotenone; sterilized tobacco dust used as the diluent, with a commercially-prepared, water-soluble sulfonate of petroleum hydrocarbons as a wetting agent, used dry, 1 part to 100 parts of dust.

3. A pyrethrum powder, containing exhausted pyrethrum flowers with .5 percent of adsorbed pyrethrins, with added antioxident 0.2 percent of a petroleum oil.

4. A spray suspension consisting of 2 pounds of cubé root powder containing 4 percent of rotenone, in 400 gallons of water, with the same wetting agent mentioned for material No. 3, one part to 800 parts, by weight, of insecticidal mixture.

5. A spray consisting of cubé powder containing 4 percent rotenone, 0.5 ounce; alcoholic extract containing 2 percent of pyrethrins, 2 fluid ounces; sulfonated castor oil, 1.5 fluid ounces, in water 3.125 gallons.

6. Untreated check.

Applications were commenced on June 6 and were discontinued when the plant size made further treatment unfeasible. Each of the dusts was applied 12 times at semiweekly intervals when the weather permitted. The rate of application ranged from 6 to 8 pounds per acre at the beginning of the season to 12 pounds per acre as the plants grew. The sprays were applied at the rate of 40 to 80 gallons per acre, at the same intervals as the dusts, but were discontinued after July 14. Ten spray applications were made.

The test plots were replicated six times and were arranged at random in a Latin square. Each plot consisted of one bent of shade-grown tobacco, or one-fortieth acre. Counts of live insects were made on 10 sample plants chosen at random in each plot before, and 24 hours after, each application of the insecticidal materials. As in previous years, four primings of three leaves each were harvested from 10 plants, also chosen at random, in each plot. These leaves were then cured in the usual commercial fashion and examined for evidences of insect injury and commercial damage.

Three criteria were used in judging the results of this season's experiments: The insect population during the growing period of the crop, the percentage of leaves showing evidences of feeding by the two insects (injury), and the percentage of the total potential wrappers (four per leaf) showing commercial damage. Treatment No. 3 was significantly better than any of the others except treatment No. 5 in reducing the thrips population, the percentage of leaves injured, and the percentage of wrappers damaged. It was also significantly better than treatment No. 5 in the control of flea beetles. All treatments except No. 5 were significantly better than lack of treatment in the control of this latter insect, while none of the treatments other than No. 3 was significantly better than the untreated check in the control of thrips. These data are shown in Table 9. Because of the unusual dryness of the season as well as the lack of further corroborative experiments, recommendations concerning the various materials cannot yet be made. 
Table 9. Data on the Control of Flea Beetles and Thrips, Windsor, Conn., $1939^{1}$

\begin{tabular}{ccccccc}
\hline \hline & \multicolumn{3}{c}{ Flea Bectle } & \multicolumn{3}{c}{ Thrips } \\
\cline { 2 - 7 } Treatments & $\begin{array}{c}\text { Relative } \\
\text { population }\end{array}$ & $\begin{array}{c}\text { Leaves } \\
\text { injured }\end{array}$ & $\begin{array}{c}\text { Wrappers } \\
\text { damaged }\end{array}$ & $\begin{array}{c}\text { Relative } \\
\text { population }\end{array}$ & $\begin{array}{c}\text { Leaves } \\
\text { injured }\end{array}$ & $\begin{array}{c}\text { Wrappers } \\
\text { damaged }\end{array}$ \\
\hline & Number & Percent & Percent & Number & Percent & Percent \\
1 & 281 & 10.2 & 4.3 & 181 & 61.4 & 19.5 \\
2 & 356 & 6.7 & 2.7 & 159 & 76.7 & 26.6 \\
3 & 387 & 3.8 & 1.2 & 30 & 46.7 & 6.5 \\
4 & 745 & 10.4 & 5.2 & 143 & 69.0 & 20.3 \\
5 & 425 & 19.5 & 3.8 & 101 & 65.9 & 14.3 \\
6 & 1446 & 25.7 & 14.9 & 138 & 70.3 & 20.6 \\
\hline Sig. dif. ${ }^{3}$ & 294.6 & 14.2 & 4.7 & 71.9 & 17.0 & 11.6 \\
\hline \hline
\end{tabular}

1 An average of $\mathbf{5 8 7 . 8}$ leaves was cured per plot and examined for insect injury and damage.

${ }^{2}$ Injury includes all insect feediug whether commercial damage or not. Damage refers only to commercial loss.

s Figures given are differences which are of statistical significance. If treatment totals differ by this amount or more, treatments are significantly different.

\section{Wireworm Control Experiments}

On May 1, twelve plots, one-twentieth acre in area (33 by 66 feet) were treated with naphthalene at the rate of 800 pounds per acre, applied in 9-inch deep furrows, 9 inches apart, and later harrowed. Twelve similar plots were plowed and harrowed at the same time but were not treated with naphthalene. The 24 plots were arranged in randomized blocks. Three samples, each containing one cubic foot of soil, were selected at random and sifted in each plot before and at weekly intervals after treatment to determine the wireworm population. These samples were taken in the rows of plants following setting, though otherwise still at random. A 6-foot border was left unsampled in each plot in order to minimize the effect of the horizontal movement of wireworms and possibly of the vaporized naphthalene. The effect on the plants was studied by recording the number of plants that died.

Samples made on May 1, the date of application, showed an average infestation of $1.74 \pm .17$ wireworms per cubic foot, there being no appreciable difference in the infestations of the areas assigned to the two different treatments. The soil temperatures at the times of sampling rose slowly from 49 degrees $\mathrm{F}$. on the date of application to 70.5 degrees $\mathrm{F}$. six weeks later. The average reduction of wireworms at this time in the treated plots was 48.0 percent, a difference which is statistically significant. There was a corresponding decrease of 19 percent in the number of plants that died but this might be attributed to experimental error.

While it was thus proved that naphthalene can be applied during cold weather and still become effective when temperatures later become favorable, the control was inadequate, possibly due to the application being made so far in advance of warm weather and the setting of the tobacco plants. Cold weather does not favor the vaporization of the naphthalene and apparently insufficient quantities were liberated prior to June 1. 
Treatment, similar to that made this year but unreplicated, which was made on June 15 in 1937, resulted in almost complete subsidence of the wireworm population in the treated area. ${ }^{1}$ These results were not mathematically significant but it seems probable that more adequate control could be attained in the present experiments by applying the material later in the year or in somewhat larger quantities.

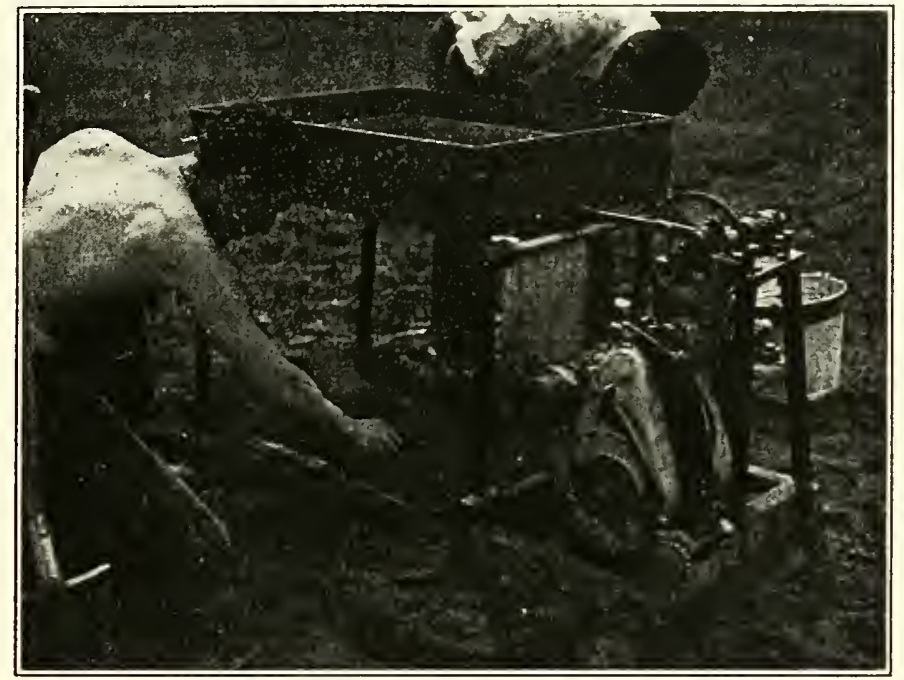

Frgune 7. Soil sifting apparatus used for determining wireworm population in treated and untreated areas. Windsor, Connecticut, 1939

\section{Insect Abundance During 1939}

The first record of actual feeding on tobacco by the Japanese beetle, Popillia japonica Newman, occurred on July 17, 1939, in two fields of shade grown tobacco in East Hartford. The heaviest infestation appeared to center in one corner of one field which had been washed out by heavy rains at the time of the hurricane in 1938. These washed places had been filled with sod taken from a nearby area beside the other infested shade tent. A moderate infestation was observed on wild grape and weeds surrounding the tents. The injury to plants was limited to the top leaves and was negligible considering the number of adults present. It was apparently due to propinquity rather than choice on the part of the beetles although individuals brought to the laboratory continued to prefer tobacco to grape leaves. Several growers reported slight attacks by the beetles on sun-grown tobacco during the season.

The wireworm Limonius agonus Say, was more injurious to tobacco this season than in 1938 but did not continue to damage the tobacco after the early, normally wet part of the season.

1 Conn. Agr. Expt. Station Bul. 410, p. 447. 
The potato flea beetle, Epitrix cucumeris Harr. was abundant until the middle of June but the summer brood was very light. A slight increase occurred unusually late, after the tobacco was harvested.

Grasshoppers were not generally as serious as usual but could be found in small numbers around almost any field of sun-grown tobacco. The common forms, as usual, were the Carolina grasshopper, Dissosteira carolina L., and the red-legged grasshopper, Melanoplus femur-rubrum DeG.

The tobacco thrips, Frankliniella fusca Hinds, was very abundant and did considerable damage to tobacco throughout the Valley. It was found on every plantation visited and at the end of the abnormally dry season was noted even on the top suckers of shade-grown plants.

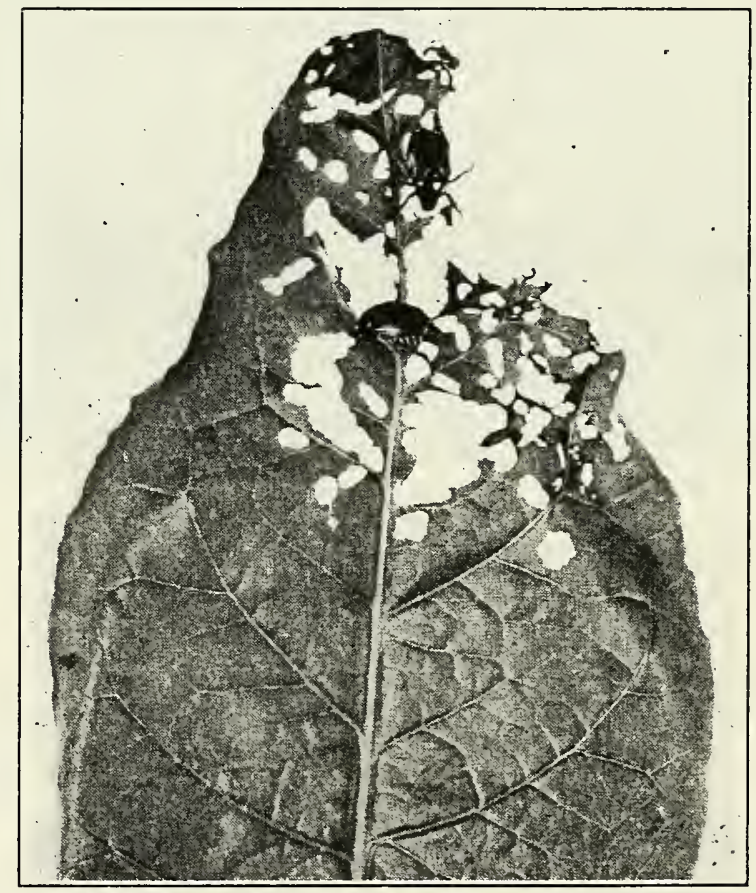

Figure 8. Japanese beetles feeding on a leaf of shade-grown tobacco, taken from near the top of the plant, East Hartford, Connecticut, July 17, 1939

No specimens of the tobacco budworm, Heliothis virescens F., were observed. Cutworms were not reported as doing any appreciable damage and hornworms were not generally numerous. A few plantations in widely separated towns were found to be moderately infested and one severe infestation of the southern or "tomato" hornworm, Protoparce sexta Johan., was seen in West Suffield.

The seed corn maggot, Hylemya cilicrura Rond., caused some damage to isolated fields. More growers than usual were affected but, as usual, one resetting served to eliminate the damage. 
The spined stink bug, Euschistus variolarius Beaur., and the tarnished plant bug, Lygus pratensis L., were found occasionally but did less damage than usual.

No damage to seedbeds from the garden springtail, Bourletiella hortensis Fitch, was seen, but mechanical damage caused by the tunnelling of small Staphylinid beetles was observed in Suffield.

Extreme damage by the potato flea beetle to tobacco planted near potato fields was again observed. As reported in 1938, plants on the edge of tobacco fields adjoining potatoes were frequently nearly completely skeletonized.

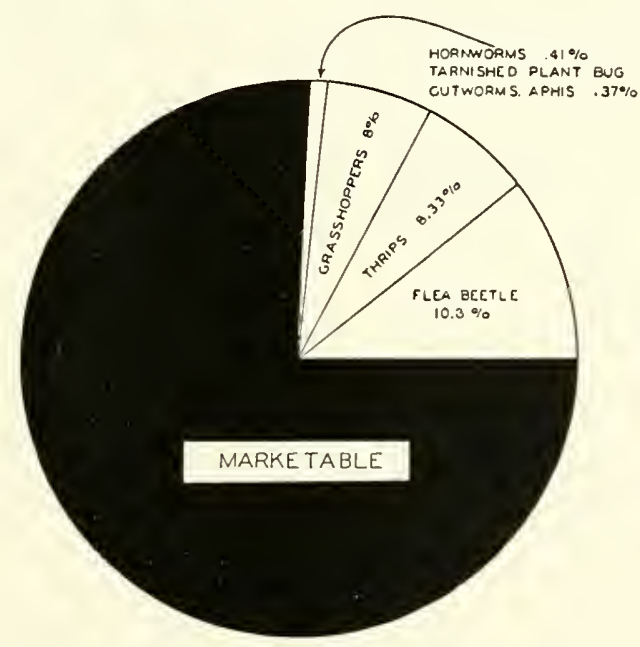

FigURE 9. Graph showing the estimated average damage by some of the principal insect pests of sun-grown tobacco, as determined by a series of field exminations made immediately before harvest in the Connecticut River Valley, 1939

Following the same method adopted in 1937, an estimate was made of the total losses sustained in sun-grown tobacco from each insect, based on the ratio of leaves damaged to those undamaged. Twenty-two fields were examined for insect damage. Five plants were chosen at random in the center and five in each quarter of the fields, and an estimate of the insect damage to every leaf on each of these plants was recorded. The average of these estimates is presented in graphical form in Figure 9.

\section{Thrips and Flea Beetle Control Experiments}

\section{S. LACROIX ${ }^{1}$.}

In addition to the experiments on the control of thrips and flea beetles which were run in coöperation with the United States Bureau of Entomology and Plant Quarantine, experiments were conducted with three

1 The cooperation of Mr. A. W. Morrill of the Bureau of Entomology and Plant Quarantine, U.S. D. A. is gratefully acknowledged. 
sprays on shade-grown tobacco and three dusts on sun-grown tobacco. In the spray tests, the treatments were as follows:

1. Proprietary rotenone compound ${ }^{2}$ containing 2.5 percent of rotenone, 1.333 ounces per gallon.

2. Mixture containing tartar emetic. 4 ounces, and brown sugar, 16 ounces, to 6 gallons of water.

3. Proprietary rotenone compound ${ }^{3}, 1.75$ ounces per gallon.

4. Untreated check.

These materials were applied with hand sprayers at rates varying from 80 to 120 gallons per acre. Each of the four treatments was applied to three plots, one-third bent, or 33 by 11 feet, in size, and arranged at random.

Table 10. Results of Examination of Cuned leaves and Counts of Insect Population, Flea Beetle and Thrips Toxicity Tests on Shade-Grown Tobacco, Windsor, ConN., 1939

\begin{tabular}{|c|c|c|c|c|c|c|c|}
\hline Plot & $\begin{array}{c}\text { Population } \\
\text { per plant } \\
\text { before } \\
\text { treatment }\end{array}$ & $\begin{array}{c}\text { Average } \\
\text { population } \\
\text { per plant } \\
\text { during season }\end{array}$ & $\begin{array}{c}\text { Number } \\
\text { curred } \\
\text { leaves } \\
\text { examined }\end{array}$ & $\begin{array}{c}\text { No. I } \\
\text { Injury } \\
\text { only }\end{array}$ & $\begin{array}{l}\text { es showing } \\
\text { Damage } \\
\text { above 50\% }\end{array}$ & $\begin{array}{c}\text { Total } \\
\text { leaves } \\
\text { injured }\end{array}$ & $\begin{array}{l}\text { Percent } \\
\text { leaves } \\
\text { injured }\end{array}$ \\
\hline \multicolumn{8}{|c|}{ Thrips } \\
\hline $\begin{array}{l}1 \\
2 \\
3 \\
4\end{array}$ & $\begin{array}{l}47 \\
40 \\
57 \\
51\end{array}$ & $\begin{array}{l}172.2 \\
131.2 \\
138.8 \\
185.0\end{array}$ & $\begin{array}{l}118 \\
104 \\
123 \\
93\end{array}$ & $\begin{array}{r}14 \\
19 \\
8 \\
8\end{array}$ & $\begin{array}{l}32 \\
15 \\
52 \\
42\end{array}$ & $\begin{array}{l}82 \\
47 \\
85 \\
59\end{array}$ & $\begin{array}{l}69.5 \\
45.2 \\
69.1 \\
63.4\end{array}$ \\
\hline \multicolumn{8}{|c|}{ Flea beetle } \\
\hline $\begin{array}{l}1 \\
2 \\
3 \\
4\end{array}$ & $\begin{array}{l}1 \\
1 \\
2 \\
1\end{array}$ & $\begin{array}{r}6.5 \\
3.2 \\
5.6 \\
26.2\end{array}$ & $\begin{array}{r}118 \\
104 \\
123 \\
93\end{array}$ & $\begin{array}{l}5 \\
2 \\
6 \\
5\end{array}$ & $\begin{array}{l}7 \\
0 \\
2 \\
4\end{array}$ & $\begin{array}{r}18 \\
2 \\
9 \\
11\end{array}$ & $\begin{array}{r}15.3 \\
1.9 \\
73 \\
11.8\end{array}$ \\
\hline
\end{tabular}

1 Injury includes all insect feeding; damage is injury which is of commercial importance. "Injury only" means injury exclusive of that which is damaged commercially.

Counts of live insects were made on 10 plants selected at random within each plot. As in the case of the coöperative experiments discussed previously, they were made immediately prior to each application and again 24 hours afterward when conditions permitted. An examination of the cured leaves was also made at the time of sorting, and records were kept of those showing insect damage. The data are given in Table 10.

While the differences in thrips population were not great enough to be of importance, there were marked differences between the flea beetle populations of the treated and the untreated plots. It will be seen in Table 10 that treatment No. 2, tartar emetic, showed the smallest number of beetles. The usefulness of this material, however, is questionable, due to its violently toxic nature and the possibility of residue. 
In the second test, with dusts on Havana Seed tobacco, the following treatments were applied:

1. Cubé, diluted with tobacco dust to a rotenone content of 1 percent.

2. Cubé, as above, with commercially-prepared, water-soluble sulfonate of petroleum hydrocarbons added as a wetting and sticking agent, dry, $1-800 .^{*}$

3. Exhausted pyrethrum flowers, impregnated with 0.5 percent of pyrethrins.

4. Untreated check.

Each of these materials was applied on plots one-twenty-fifth of an acre in area. Applications were made on July 14, 18, 21, 25, 28 and 31. As with the sprays, counts were made immediately prior to each application and 24 hours thereafter when weather permitted.

These counts indicate that pyrethrum was the most effective in controlling both the flea beetle and the thrips. The data are given in Table 11.

Table 11. Results of Counts for Populations of Live Insects; Flea Beetle and Thrips Toxicity Tests on Havana Seed Tobacco, Windsor, Conn., 1939

\begin{tabular}{|c|c|c|c|c|c|c|c|c|}
\hline \multirow[t]{2}{*}{ Date } & \multicolumn{4}{|c|}{$\begin{array}{c}\text { Flea Beetle' } \\
\text { Plot Number }\end{array}$} & \multicolumn{4}{|c|}{$\begin{array}{l}\text { Thrips }{ }^{2} \\
\text { Plot Number }\end{array}$} \\
\hline & 1 & 2 & 3 & 4 & 1 & 2 & 3 & 4 \\
\hline July $14^{3}$ & 9 & 17 & 4 & 4 & 68 & 129 & 45 & 61 \\
\hline July 17 & 0 & 4 & 0 & 1 & 55 & 109 & 32 & 65 \\
\hline " 19 & 4 & 3 & 1 & 6 & 71 & 97 & 21 & 90 \\
\hline " 21 & 4 & 0 & 0 & 5 & 38 & 58 & 5 & 86 \\
\hline “ 22 & 0 & 4 & 0 & 5 & 47 & 76 & 3 & 120 \\
\hline “ 25 & 2 & 7 & 1 & 0 & 17 & 78 & 5 & 49 \\
\hline “ 27 & 3 & 2 & 0 & 17 & 50 & 71 & 4 & 58 \\
\hline “ 28 & 7 & $2 \overline{3}$ & 6 & 20 & 26 & 56 & 11 & 109 \\
\hline “" 29 & 0 & 2 & 2 & 22 & 61 & 85 & 4 & 50 \\
\hline \multirow[t]{2}{*}{ Aug. 1} & 4 & 19 & 1 & 25 & 41 & 56 & 11 & 63 \\
\hline & 24 & 64 & 11 & 101 & 406 & 686 & 96 & 690 \\
\hline
\end{tabular}

1 Significant difference-39

: Significant difference-123

3 Count made before first application, not included in totals.

\section{FURTHER EXPERIMENTS ON CONTROL OF DOWNY MILDEW}

\section{P. J. ANderson}

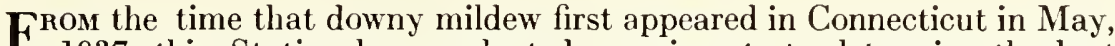
1937, this Station has conducted experiments to determine the best method of checking the disease. Results of these have appeared in the following publications:

Downy Mildew of Tobacco. Conn. Agr. Exp. Sta. Bul. 405. December, 1937

Downy Mildew. Conn. Agr. Exp. Sta. Bul. 422: 26. 1938

Control of Tobacco Mildew (Blue Mold) in Seedbeds. Conn. Agr. Exp. Sta. Circ. 128. January, 1939

Diseases and Decays of Connecticut Tobacco. Conn. Agr. Exp. Sta. Bul. 432, March, 1940

* Ultrawet 
In these publications it was shown that none of the spray materials tried has given satisfactory results but that successful control was obtained by "gassing" the beds with benzol or with paradichlorobenzene. Success with either of these materials depends, however, on ability to secure a sufficiently high concentration of the gas in the air of the seedbed to stop the growth of the mildew fungus. The concentration depends, in turn, on the surface exposure of the chemical, its rate of evaporation and its rate of escape from the beds. A high rate of evaporation and a high surface exposure may be entirely nullified by loose beds or other conditions that offer opportunities for rapid escape.

Concentration of benzol gas required for control. In a series of beds in Hazardville, 1938, benzol was applied each night by placing one pan (10 inches in diameter) every 9 feet under glass sash. But the mildew continued to spread. In order to find the explanation for the failure, readings with the M. S. A. indicator ${ }^{1}$ were made (Frontispiece) at every hour of the night. None of the readings showed a concentration higher than .03 percent. Examination of the beds next day revealed that there were so many openings in the glass, between the sash, through cracks and under the sideboards, that it was impossible to build up a lethal concentration. Even when the number of pans was increased to one to every 6 feet, the concentration was not high enough. The owner then made the beds tighter by replacing broken glass, piling up the soil against the sideboards, stopping cracks with wet cloth and nailing slats over the wider cracks. When the gas concentration was measured throughout the following night it varied from .06 percent to .16 percent in different parts of the beds. Within 48 hours the disease had stopped and there was no further trouble. During the seedbed seasons of 1938 and 1939, in tests similar to the Hazardville experiment, thousands of readings were made on beds throughout the Valley. As a result of these, it was concluded that a concentration of at least .05 percent is necessary to.insure control. Approximately the same conclusion was drawn by Gumaer ${ }^{2}$ and by other investigators in the Southern States.

Just how long the concentration must be kept up to this point has not been fully determined. It is known that the spores of the fungus are developed after midnight or in the very early hours of the morning and obviously this is the critical time. Probably it is not necessary to maintain the concentration all night. With a little experience one learns to distinguish fresh sporulation but it is not always possible to tell the first morning after treatment whether mildew has been stopped. But on the second day, if the treatment has been adequate, the old spores have dried up and no fresh sporulation will be seen.

Glass sash vs. cloth covers. It is a common belief that glass bed covers are tighter than continuous cloth covers and would therefore be more suitable for confining the air and thus building up the concentration of fungicidal gas. In order to see whether this assumption is warranted, a number of tests were made in which the concentration of benzol vapor was

1 The readings were made with the aid of an instrument known as a Mine Safety Appliance kindly loaned by Mr. P. W. Gumaer who also spent a great deal of time at the Station and furnished invaluable assistance in conducting these experiments.

2 Gumaer, P. Wilcox. Control of blue mold of tobacco with benzol vapor. Indus. and Eng. Chem. 30: 1076-1081. 1938 . 
measured by the M. S. A. Indicator at intervals throughout the night in adjacent beds, one having average glass sash and the other covered with cloth. It will be necessary to describe only one of these tests since all gave similar results.

On May 21, 1938, mildew had appeared in some of the beds on a plantation in West Suffield. Three beds were used for this experiment. From one, the glass sash were removed and the bed was covered with cloth of 56 by 60 mesh. The cloth was sprinkled with water at sundown and remained damp throughout the night. Pans of benzol (10 inches diameter) were supported on heavy wire hoops above the plants, spaced 6 feet apart. An adjacent bed received the same benzol treatment but was covered with the ordinary glass sash. A third bed differed only in that the benzol pans were 9 feet apart. The night was calm and the average temperature about 50 degrees $\mathrm{F}$. The gas was tested each hour of the night at three different locations in each bed by drawing out a sample through a three-sixteenths inch brass tube which had previously been inserted through the sideboards. The average concentration for each hour of the night is shown in Table 12 and graphically in Figure 10.

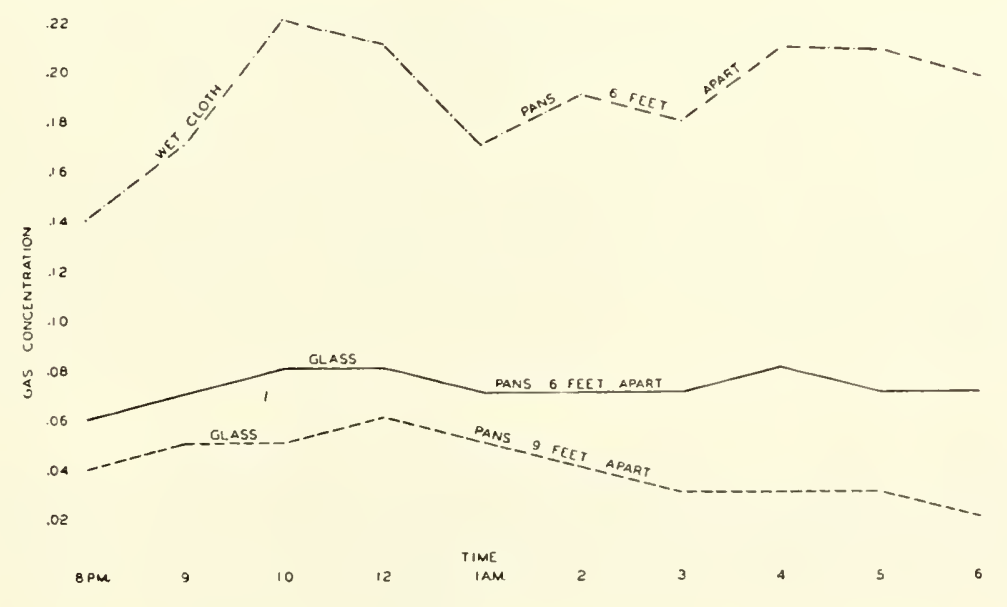

Figure 10. Concentration of benzol gas under cloth and under glass.

The results show that the wet cloth is much more effective in confining the air than is the glass. The reason for this difference is obvious. The cloth is drawn tightly over the edges of the boards and the water in the cloth seals up all the spaces between the threads. The sash, however, usually do not fit tightly on the sideboards, and there are cracks between them. Also between the glass panes there are usually small openings which allow some gas escape.

These treatments were repeated the next night and then on alternate nights. After the first 48 hours there was no further development of mildew in any of the beds. A still more striking contrast between glassand cloth-covered beds is shown by the experiment represented in Table 15 and Figure 13. 
Dry cloth vs. wet cloth. Gumaer has shown by experiments in North Carolina (previous citation) that dry cloth covers, even as dense as 68 by 72 mesh, are not effective in building up a lethal concentration. When the spaces between the threads of the cloth are not sealed with water, the gas passes quickly through into the outer air. No experiments for comparing dry with wet cloth were conducted here but some observations incidental to the other experiments confirmed his conclusion. In some of the experiments, breezes during the night dried the cloth which had been sprinkled at sundown. Previous readings had shown the concentration of gas well above the critical .05 concentration. An hour after the cloth became dry the concentration had dropped below .02 percent. Some growers use cloth covers regularly in place of glass. A number of them have reported failure to get control with benzol except where the cloth was wet by dew or rain, or was sprinkled at sundown. As a rule, sprinkling at sundown insures wetness throughout the night because heavy dews, common at this time of year, prevent the cloth from drying out. Dry cloth is much less effective than glass.

Table 12. Comparison of Glass Sash Cover with Wet Cloth Cover. West Suffield, MaY 21, 1938

\begin{tabular}{|c|c|c|c|c|c|c|c|c|c|c|}
\hline \multirow{3}{*}{$\begin{array}{c}\begin{array}{c}\text { Distance } \\
\text { between } \\
\text { pans }\end{array} \\
\text { Cover }\end{array}$} & \multicolumn{10}{|c|}{ Concentration of Gas at } \\
\hline & \multicolumn{4}{|c|}{ P. M. } & \multicolumn{6}{|c|}{ A. M. } \\
\hline & 8 & 9 & 10 & 12 & 1 & 2 & 3 & 4 & 5 & 6 \\
\hline Cloth & .14 & .17 & .22 & .21 & .17 & .19 & .18 & .21 & .21 & .20 \\
\hline Glass & .06 & .07 & .08 & .08 & .07 & .07 & .07 & .08 & .07 & .07 \\
\hline Glass 9" & .04 & .05 & .05 & .06 & .05 & .04 & .03 & .03 & .03 & .02 \\
\hline \multicolumn{11}{|l|}{ Fahrenheit } \\
\hline Temperature & 64 & 52 & 52 & 53 & 48 & 48 & 48 & 52 & 52 & 53 \\
\hline
\end{tabular}

Cloth covers over the glass. Since most growers have their beds covered with glass sash they feel that it is more convenient to spread a cloth over the glass than to remove the sash. To test the effectiveness of this method the following experiment was conducted on the shade beds at a farm in Windsor where mildew had already started in 1938.

In one bed with ordinary glass sash, pans were placed 6 feet apart. No cloth cover was used.

The second bed with glass sash was also covered with wet cloth ( 56 by 60 mesh) and pans were placed 9 feet apart. The cloth extended over the edges of the sash and was nailed to the sideboards.

The third bed was treated the same as the second but the pans were set 12 feet apart.

In the fourth bed, there was a similar arrangement but the cloth was not nailed. Where the edges of the cloth lay on the ground, it was held in place by loose boards.

The cloth was sprinkled at sundown. Readings were taken in three or four locations in each bed at intervals throughout the night of May 27 with results as indicated in Table 13 and shown graphically in Figure 11. 
Table 13. Effect of Cloth Covers Over Glass Sash. May 27, 1938

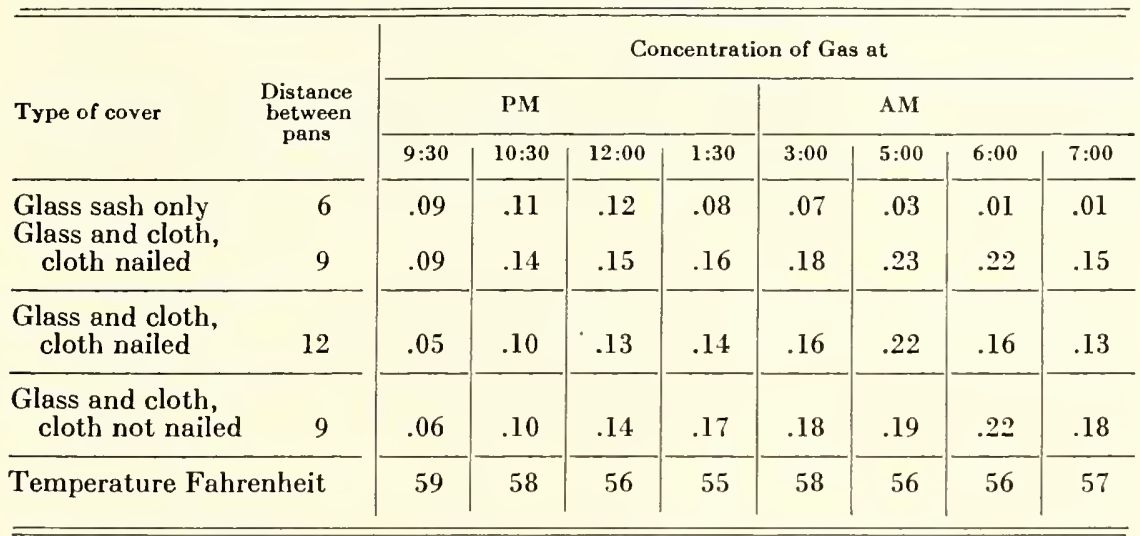

The night was warm and calm with a heavy dew and no wind, conditions which favored even the glass bed without cover. The concentration in this bed, however, began to drop at midnight and sank below the effective point before morning. In all of the beds with cloth over the glass, the concentration remained very high all through the night even though the number of benzol pans was less than in the glass covered bed. Even where the pans were spaced 12 feet apart-only half as many pans as in the bed with glass alone - the concentration remained well above the safety point. It made little difference whether the cloth was nailed to the sides of the bed or left on the ground at the edges. Although this method involves the use of wider strips of cloth, it reduces the consumption of benzol by one-half.

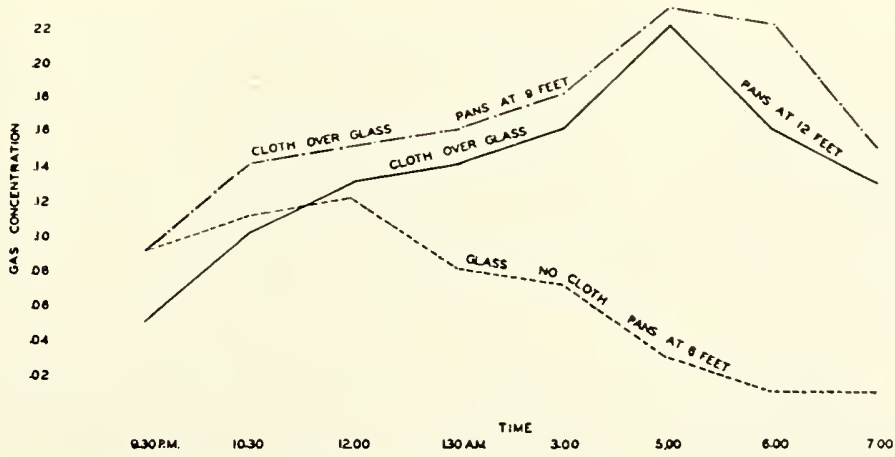

Figure 11. Effect of wet cloth ( 56 by 60 mesh) over the glass sash on the concentration of benzol vapor.

Since the growers of shade tobacco always have on hand quantities of old shade cloth, there would be some economy in using this in place of the heavier 56 by 60 mesh cloth if it were effective. Several experiments 
were tried to determine this point. One of these on the beds at the Station was as follows:

On the night of May 31, 1938, four thicknesses of shade cloth were spread over one end ( 75 feet) of a bed while the other end was left with the glass sash bare. A board partition separated the two. Benzol pans were distributed in the beds 6 feet apart. The clotl was sprinkled at sundown. Readings taken at each hour of the night are recorded in Table 14 and slown graphically in Figure 12.

The results from this and other similar tests on growers' beds show that wet shade cloth over the glass increases effectively the concentration of gas in the beds. This cloth remained wet throughout the night. If the cloth were doubled so that several thicknesses covered the bed, undoubtedly the effectiveness would be increased.

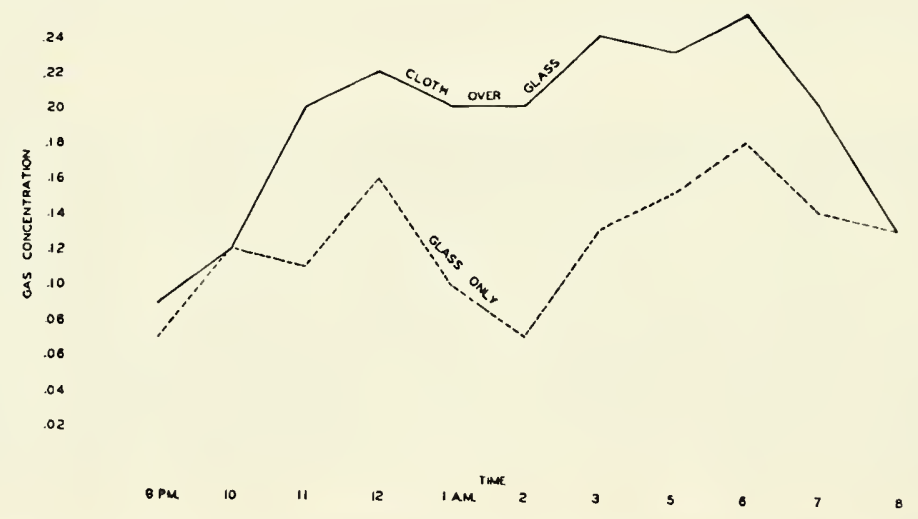

Figure 12. Effect of covering glass sash with four thicknesses of wet shade cloth on the concentration of benzol vapor

Thickness of cloth. The cloth which was used in most of these experiments was unbleached sheeting with 56 threads to the inch one way and 60 in the other direction, weighing one pound to 4 square yards. Since new cloth does not absorb water readily it should first be washed in a barrel of water containing strong washing powder (warm water is best) to remove the "sizing" from it. After this treatment it will readily absorb water when sprinkled. This weight of cloth was first used because experiments in the South made by Gumaer had showed that lighter cloth was not practical. Failures of some of the growers here who used lighter cloth (without glass) confirmed Gumaer's results. Shade cloth without glass, even when folded in six or eight thicknesses and sprinkled, was found to be ineffective in confining the gas.

One test was made to see whether a still heavier cloth would be better. At H. C. Thrall's farm, one bed was covered with the usual 56 by 60 cloth (no glass), one with an 80 by 80 mesh, while a third bed was covered with glass sash. These beds were 6 feet wide and the benzol pans (10-inch diameter) were spaced 6 feet apart. Readings of the vapor concentration throughout one night, May 25, are shown in Table 15. 
It may be seen from the table and graph (Figure 13) that the thicker cloth increased the gas concentration throughout the night. Since both types of cloth produced a concentration well above the safety point, probably the extra cost of thicker cloth is not warranted. The concentration was so high that in later treatments the distance between pans was increased to 9 feet and still mildew was completely stopped.

Table 14, Effect of Wet Shade Cloth Over the Glass Sash. Station Beds MAY 31,1938

\begin{tabular}{|c|c|c|c|c|c|c|c|c|c|c|c|}
\hline \multirow{3}{*}{ Covering } & \multicolumn{11}{|c|}{ Gas Concentration at } \\
\hline & \multicolumn{4}{|c|}{ PM } & \multicolumn{7}{|c|}{ AM } \\
\hline & 9 & 10 & 11 & 12 & 1 & 2 & 3 & 5 & 6 & 7 & 8 \\
\hline Glass sash only & .07 & .12 & .11 & .16 & .10 & .07 & .13 & .15 & .18 & .14 & .13 \\
\hline Sash covered with shade cloth & .09 & 12 & .20 & .22 & .20 & .20 & .24 & .23 & .25 & .20 & .13 \\
\hline Temperature Fahrenheit & 56 & 51 & 49 & 46 & 45 & 44 & 42 & 42 & 43 & 47 & 52 \\
\hline
\end{tabular}

Table 15. Comparison of Cloth of Different Weights. Thrall's May 25

\begin{tabular}{|c|c|c|c|c|c|c|}
\hline \multirow{3}{*}{ Type of Cover } & \multicolumn{6}{|c|}{ Gas Concentration at } \\
\hline & \multicolumn{2}{|c|}{$P M$} & \multicolumn{4}{|c|}{ AMI } \\
\hline & 9 & $10: 30$ & $12: 15$ & $1: 45$ & $3: 00$ & $4: 30$ \\
\hline $\begin{array}{l}\text { Glass sash } \\
56 \times 60 \text { cloth } \\
80 \times 80 \text { " } \\
\text { Temperature Fahrenheit } \\
\text { Weather }\end{array}$ & $\begin{array}{r}.02 \\
.11 \\
.14 \\
55 \\
\mathrm{Lig} \\
\mathrm{n}\end{array}$ & $\begin{array}{c}.02 \\
.13 \\
.18 \\
50 \\
\text { ind } \\
w\end{array}$ & $\begin{array}{l}.02 \\
.18 \\
.22 \\
47 \\
\text { No }\end{array}$ & $\begin{array}{r}.07 \\
.23 \\
.27 \\
43 \\
\text { d. D } \\
\text { Fog a }\end{array}$ & $\begin{array}{c}.09 \\
.25 \\
.30 \\
41 \\
\text { starte } \\
3: 00 .\end{array}$ & $\begin{array}{c}.08 \\
.24 \\
.30 \\
38 \\
12 .\end{array}$ \\
\hline
\end{tabular}

This experiment was also instructive in showing what effect the atmospheric condition may have on gas concentration under glass sash. Up until midnight a light breeze was blowing and there was no dew. Under these conditions it was not possible to build up a concentration in the glasscovered bed sufficient to insure control of mildew. About midnight the wind died and dew began to collect on the glass. The graph (Figure 13) shows how the gas concentration began to rise as soon as the wind stopped and the dew began to form. This was further accentuated by a fog which started at about 3:00 A.M.

Sprinkling the glass sash with water. In the experiment just recorded and in the course of a number of other experiments where concentration readings were made at hourly intervals throughout the night, it was always noticed that as soon as the sash were covered with dew, the gas concentration started to rise. These observations suggested that the same results might be obtained by sprinkling the glass sash with water at sundown from a hose. The experiment described below shows that this assumption was correct.

On one-half of a 150-foot bed, the sash were sprinkled and those on the other half left dry. Pans were set at 6-foot intervals. The hourly 
readings taken at three points in each end are recorded in Table 16 and shown graphically in Figure 14.

The curves of concentration shown in Figure 14, considered in connection with the atmospheric conditions, are very instructive. The benzol was distributed in the beds at 7 P.M. and the sash on one end sprinkled immediately afterward. The weather was breezy until midnight. At 9 P.M. the concentration on the sprinkled end was well above the safety

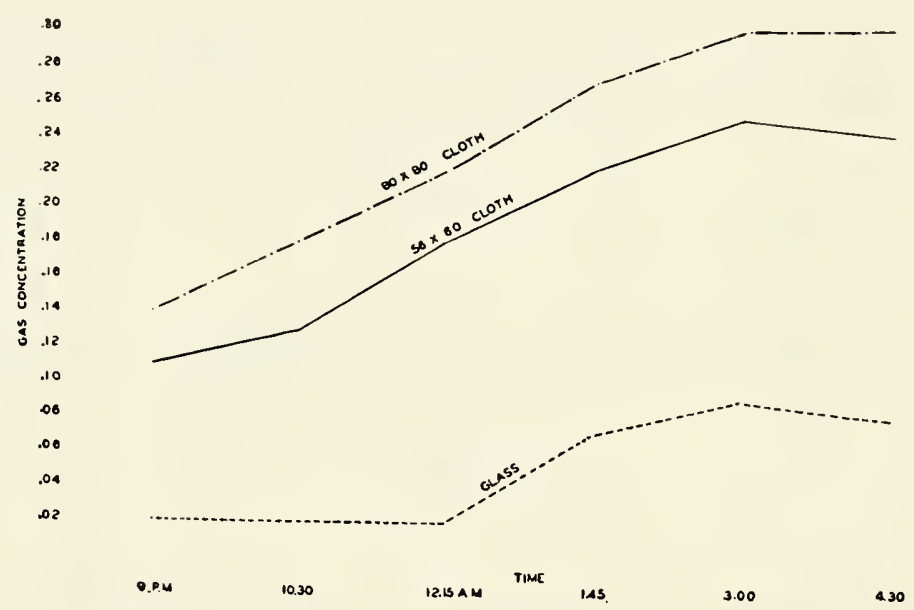

Figune 13. Cloth of two different thicknesses compared with glass sash. Effect on benzol vapor concentration.

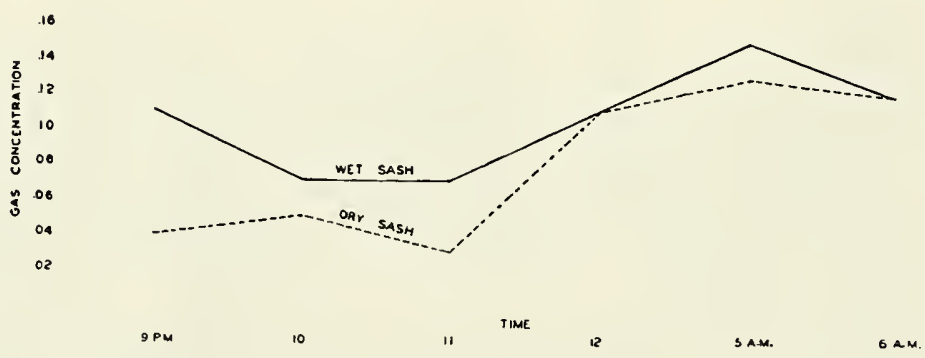

Figure 14. Effect of sprinkling the sash with water on the concentration of benzol vapor in the beds.

point while on the dry end it was hardly sufficient to insure control. The concentration dropped later, even in the wet sash end, because a light wind was drying the sash. Still the concentration remained sufficiently high for control. About the middle of the night the dew began to form and the breeze died. After the sash were covered with dew, conditions were about the same at both ends of the bed and there were no significant differences 
in concentration of gas. This experiment demonstrated clearly the advantage of sprinkling the glass with water but also showed that during a windy night the advantage may be nullified by failure of the sash to remain moist. One of the advantages of covering the glass with wet shade cloth is that the cloth retains the water and kecps the sash wet all night even when there is no dew.

During some of the experiments there were light rains during the night. This always resulted in a rise in gas concentration in the beds.

The water from dew, rain or sprinkling collects in the cracks between the glass or where the glass panes overlap and by sealing these openings prevents escape of the gas. The water also swells the wood of the sash and boards, thus making them tighter.

Table 16. Effect of Sprinkling the Glass Sash on Benzol Vapor Concentration. Station Beds. MaY 30, 1939

\begin{tabular}{|c|c|c|c|c|c|c|}
\hline \multirow{3}{*}{ Treatment of Glass Sash } & \multicolumn{6}{|c|}{ Gas Concentration at } \\
\hline & \multicolumn{4}{|c|}{ PM } & \multicolumn{2}{|c|}{ AM } \\
\hline & 9 & 10 & 11 & 12 & 5 & 6 \\
\hline $\begin{array}{l}\text { Dry } \\
\text { Sprinkled } \\
\text { Temperature }\end{array}$ & $\begin{array}{l}.04 \\
.11 \\
51\end{array}$ & $\begin{array}{l}.05 \\
.07 \\
49\end{array}$ & $\begin{array}{l}.03 \\
.07 \\
46\end{array}$ & $\begin{array}{l}.11 \\
.11 \\
42\end{array}$ & $\begin{array}{l}.13 \\
.15 \\
33\end{array}$ & $\begin{array}{l}.12 \\
.12 \\
35\end{array}$ \\
\hline Atmosphere & \multicolumn{3}{|c|}{ Windy, no dew } & Dew, still & \multicolumn{2}{|c|}{$\begin{array}{c}\text { Glass covered } \\
\text { with frost }\end{array}$} \\
\hline
\end{tabular}

Effect of wind on benzol vapor concentration. No experiments were set up with the purpose of measuring the effect of the wind but, in connection with all of the tests, the effect of the wind was readily observed. Wind, passing over the tops of the beds, causes a suction which draws the vapor-laden air out of the beds, and increases or decreases in wind velocity can be read quickly in changes in vapor concentration. This was most apparent in beds covered only with glass sash. But also in beds covered only with cloth, if the wind continued until the cloth was dry the concentration dropped immediately. Glass sash covered with heavy wet cloth were more independent of the effects of wind. Fortunately most of the nights during the critical period of May and early June are calm, especially after midnight-and dew collects on the sash to seal the crevices.

Temperature and control. The rate of evaporation of benzol increases rapidly as the temperature rises so that during a warm night there may be two or three times as much of the liquid evaporated as during a cold night. This naturally would result in a higher concentration of benzol gas during the warm nights. Theoretically there would be the danger that concentration during a cold night would be too low to insure control. Despite the theory, actual results have not shown this to be true. An examination of the tables presented above, where the temperatures throughout the night are recorded, and a study of many other data not recorded here, fail to show any correlation between concentration of vapor and the nightly temperature. This may partly be accounted for by the fact that the temperatures recorded were those of the air outside the bed while the temperature on the ground surface where the plants are growing probably 
does not show so wide a fluctuation. With the same number of pans in the bed, control of the disease has been as good at low temperatures-even with frost on the outside of the glass - as at higher temperatures. Some growers used pure benzol and found that it had frozen solid during the night but apparently without detriment as far as control was concerned. (Freezing does not occur when the benzol is diluted with a little toluol.) Experience up to the present leads us to believe that variations in air temperatures during the danger period here are not of any great importance as far as control with benzol is concerned. Other environmental factors are much more decisive.

Evaporation surface ratio. The rate of evaporation of benzol is proportional not to the quantity of liquid used but to the surface area of the liquid exposed to the air. This also determines the concentration of vapor obtained in the air-all other conditions being equal. The problem then is: How much surface area of benzol is required to produce an adequate vapor concentration in a given area of bed? (Theoretically we should work with cubic feet of air instead of square feet of bed, but since most beds are of about the same height, the error from variation may be disregarded.) The relation which exists between a given exposure surface of the liquid and the square feet of bed surface to be protected is called the "evaporation surface ratio". Thus the ratio of 1 to 72, which was recommended in Australia where the benzol method was first used, means one square foot of benzol surface in the evaporation pans to 72 square feet of bed surface, or 4 sash of our ordinary 6 -foot size. In view of the results in the experiments which have just been described showing the effects of various external factors, it is obvious that "evaporation surface ratio", strictly speaking, is not the determining factor in control. The decisive factor is gas concentration; but how is the grower to know what gas concentration he is getting in his beds?

If every grower could own or have available an M. S. A. Indicator and know how to use it, there would be no need to consider surface evaporation ratios and also it would be possible for everybody to get perfect control. But this is an expensive, delicate and complicated instrument and not practical for most growers. Obviously he must have some other method to guide him in his operations and, in the lack of any more exact rule, the use of the evaporation surface ratio would seem to be the best rule to use until a better method is devised. In addition to this, he will have to use some judgment. Concentration is quite dependent on tightness of beds, as previously explained. He can readily determine the condition of his beds and increase or decrease his evaporation ratio accordingly. Also he can find out by inspection of the plants within 48 hours whether or not his control is successful and can adjust the ratio - number of pans-accordingly.

Most of the growers use either pie tins of about 10-inch diameter (Frontispiece) or firing pans of the wash basin type employed for firing with charcoal. The latter have sloping sides but, if filled a quarter of an inch deep with a liquid, the surface is a little less than 10 inches in diameter. Or, in general, we may say that the surface area of any of the generally used pans is roughly one-half of a square foot. Since the usual 6-foot sash covers 18 square feet of bed, the use of one pan to each two sash gives a ratio of 1 to 72 ; one to three sash is a 1 to 108 ratio, and one to four sash is 
1 to 144 ratio. An inspection of the data presented in the preceding tables showed that adequate vapor concentration was produced and control obtained with any of the above mentioned ratios depending on the type of cover. As a result of these and a considerable number of other tests not recorded here, the following recommendations seem warranted:

1. A ratio of 1 to 108 , or one pan to three sash, if sash and beds are very tight. Sprinkling the glass recommended.

2. A ratio of 1 to 72, or one pan to two sash, for ordinary beds which are usually not very tight. Sprinkling the glass recommended.

3. Ratio of 1 to 144 , or one pan to four sash, where the glass is covered with the heavy cloth mentioned above ( 56 by 60 threads) or with several thicknesses of shade cloth, or where the heavy cloth alone is used on tight beds. All cloth should be sprinkled at sundown.

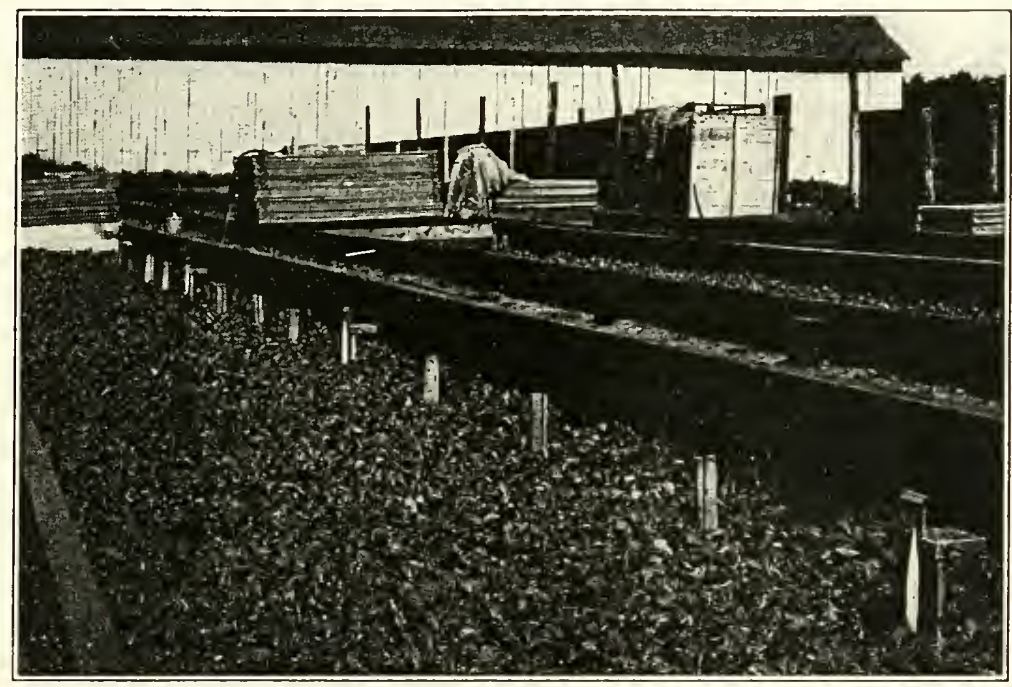

Figure 15. Four Gumaer wick evaporators for benzol installed in a tobacco bed. Note metal reservoir outside of upper end of bed.

Volume of benzol needed. Since any benzol which is not evaporated during the night may be poured back into the container and used at the next application, it is not necessary to use a carefully measured volume, but only to have enough in the pan to last all night or at least most of the night. The rate of evaporation varies with temperature, etc., as mentioned above, but in general it has been found that if the bottoms of the pans are covered with a quarter of an inch of benzol, the quantity is sufficient. Calculating on this basis, a gallon of benzol is sufficient for 13 pans; or one gallon to 26 sash on the 1 to 72 ratio, 39 sash on the 1 to 108 ratio and 52 sash on the 1 to 144 ratio. With the price of benzol at 26 cents per gallon then, the cost per sash, per treatment, is between one-half and one cent. 
When should benzol treatment start and how often should it be repeated? There seems to be no object in starting the use of benzol before the second week in May, which is the earliest date that mildew has been found here. Then repetition every second night is enough. If mildew has already been found in a bed, however, it is best to treat it two or three nights in succession until it has been stopped.

Wiek evaporators for benzol. The filling of the pans under the glass at sundown involves considerable labor at an inconvenient time of the day. Most of this may be eliminated by the use of a type of wick evaporator which is now on the market (Figure 15). Each evaporator unit is a closed metal can with a long wick, one end of which is immersed in the benzol in the can and the other end hanging down free below the can. The benzol passes into the wick by capillarity and then is evaporated into the air. These evaporators, bolted to the inside of the headboard of the bed, are spaced at regular intervals and connected one with another by small brass tubes through which the benzol flows through the whole series the length of the bed. They are all filled from a metal reservoir outside the higher end of the bed. These may be left in the bed throughout the season and the only labor required is for the operator to pour a measured amount of benzol into the reservoir. It is not necessary to raise or disturb the sash at all. A series of Gumaer wick evaporators installed in the Station beds is shown in Figure 15.

These evaporators have been tested two years at the Station and on the plantations of several growers. In all these tests the evaporators were spaced 12 feet apart. Except on one farm, where the beds were plainly too loose, mildew was satisfactorily controlled in all cases. During these tests on the Station farm in May, 1939, readings of the concentration of gas were made throughout the night for five nights. Although there was considerable variation from night to night, due mostly to atmospheric conditions, it will be noted from Table 17 that the average for each night was sufficient to insure control and there was not great difference in favor of either pan or wick, although considerably more benzol was used in the pans.

Table 17. Average Vapor Concentrations of Benzol Produced by Wick Evaporators 12 Feet Apart as Compared with Pans 9 Feet Apart

\begin{tabular}{c|c|c}
\hline \hline Date & $\begin{array}{c}\text { Vapor Concentrations, } \\
\text { Wicks }\end{array}$ & $\begin{array}{c}\text { Average for the Night } \\
\text { Open Pans }\end{array}$ \\
\hline May 18 & .12 & .05 \\
“ 19 & .05 & .06 \\
“ 23 & .06 & .08 \\
Average & .07 & .14 \\
Aver. & .12 & .12 \\
& .08 & .09 \\
\hline \hline
\end{tabular}

\section{Paradichlorobenzene}

Since it was learned that this material had given promising results against mildew in South Carolina, we started experiments with it here May 20, 1938. On one bed where mildew had already started, pie tins 
such as we were using for benzol were spaced about 4 feet apart in the center of the bed and partially pulverized crystals of paradichlorobenzene were spread in the bottom of the pans at the rate of one-half ounce to a square yard of bed surface. This was repeated three nights in succession and then every alternate night. The nights were warm, not below 50 degrees F. After the second treatment, all the mildew appeared dead and all plants remained healthy until set in the field. In an adjacent bed, where no mildew had yet appeared, sections of the bed were treated every second night with PDB at the rates of one-quarter ounce to the square yard and at one-eighth ounce to the square yard. No mildew appeared in any of these sections although it invaded untreated sections of the same bed. This led us to believe that even with amounts as low as one-eighth ounce to the square yard, mildew could be controlled.

In a later experiment, a bed was divided into sections 15 feet long and the PDB distributed on shelves 3 inches wide along both sides of the bed. One section received no treatment. To insure infection, all the bed was inoculated with spores of mildew in water which was sprinkled over the plants from a watering can. Rates of application of PDB were one-eighth, one-quarter and one-half ounce per square yard. Within 6 days after inoculation, mildew appeared on the untreated section and spread until 100 percent of the plants were affected. No mildew could be found on any of the sections that had been treated with PDB. No further experiments were undertaken that year because it was now the middle of June and with hot weather the mildew disappeared.

All tests with PDB were completely successful that spring, but it should be noted that fairly warm weather prevailed throughout the tests.

Numerous experiments in the greenhouse during the winter of 1938-39 gave similar results with the night temperature in the greenhouse about 55-60 degrees F. Complete success was obtained with all sizes of crystals up to one-quarter inch in diameter and even when the treatments were applied every third night. In these tests wire baskets instead of pans or shelves were used.

In the outdoor beds in the spring of 1939, tests were started earlier than the previous year and there were many cold nights and occasional frosts. At these temperatures, control with PDB was slow. Even after two or three treatments, mildew was not completely stopped during the cold nights.

If the treatments were continued long enough, the disease was finally checked but it was necessary to increase the dosage or make the application earlier in the evening to take advantage of a higher temperature. The whole set of tests leads us to conclude that when the night temperatures drop below 45 degrees $\mathrm{F}$., paradichlorobenzene is not as effective as benzol.

These results are not surprising in view of the known effect of variation in temperature on the rate of evaporation of paradichlorobenzene. As the temperature decreases there is a very marked decrease in the rate of evaporation. The rates at various temperatures have been investigated by several workers with results which do not agree entirely because of differences in methods of procedure. All show the same general tendency. Thus Roark and Nelson (Jour. Econ. Ent. 22: 385. 1929) found that the 
rate of evaporation at 59 degrees $\mathrm{F}$. was five times as rapid as at 32 degrees; at 68 degrees F. it was eight times as rapid as at 32 degrees. Some tests in the open air of the laboratory here showed the rate approximately doubled by increasing the temperature from' 60 to 70 degrees $F$.

This characteristic is also naturally influenced by the size of the crystals, because the amount of evaporation depends on the area of surface exposure. This, in turn, is greater when the crystals in a given weight of the material are smaller. The following experiment serves as an illustration.

As the material is marketed by the principal producers, there are 10 crystal sizes ranging from a quarter of an inch (No. l) down to a size about like granulated sugar (No. 10). The other sizes range at regular intervals between the two. Ten grams of each of four sizes were spread in thin layers in watch glasses and exposed to the air at about 70 degrees $F$. They were weighed every 24 hours. The finest material had completely evaporated in three and one-half days while it required six and one-third days for the coarsest grade to disappear. The differences in the others may be seen from the graph in Figure 16.

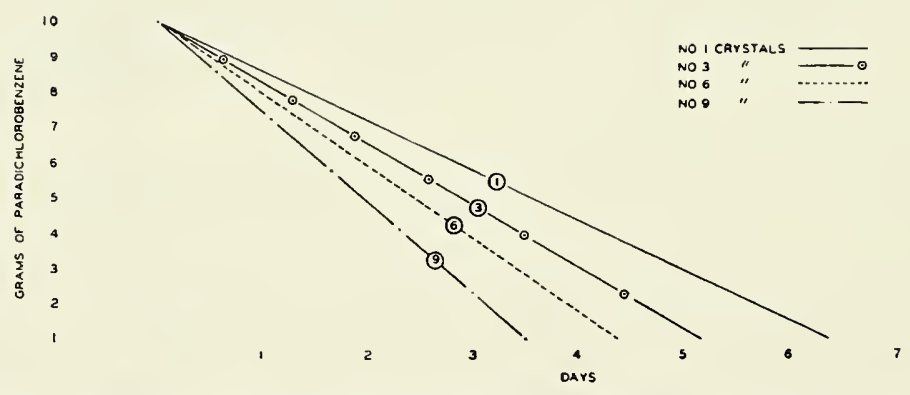

Figure 16. Effect of size of crystals of paradichlorobenzene on rate of evaporation.

It is apparent from this that if a greater concentration of gas is desired in the beds, finer crystals may be used. At fairly warm temperatures, however, it was not found necessary to use a grade finer than No. 6. Finer crystals tend to "lump" unless they are in a very thin layer. When they lump they are no more efficient than large crystals. The use of smaller" crystals may partly overcome the failure at low temperatures mentioned above but not sufficiently to overcome the temperature effect.

\section{THE ROLE OF YEAST IN THE FERMENTATION OF TOBACCO}

\section{Further Tests on Cigar Binder Types}

\section{O. E. Street ${ }^{1}$}

THE previous experiments on spraying cigar-leaf tobacco with yeast suspensions reported in 1937 (Conn. Agr. Exp. Sta. Bul. 410: 414-443) indicated that considerable benefit could be expected from treatments

1 Formerly Physiologist of the Conn. Tobacco Substation, now Agronomist in charge of Tobacco Research for U. S. D. A. at Lancaster, Penn. 
applied to a binder type under commercial conditions. Early in 1938 an arrangement was made with the Russell Warehouse, Windsor Locks, to run such a series of experiments.

The materials chosen were Havana Seed darks, seconds, and No. 2 seconds, to which were applied yeast suspensions to yield .75 percent, 1.00 percent and 1.50 percent baker's yeast computed in pounds of moist yeast to the hundred pounds of tobacco. The technique of application was simplified by first drying the tobacco carefully in 50 -pound lots, so as to lower its gross weight sufficiently to allow the application of one to two pounds of a concentrated suspension. Check weighings and moisture determinations permitted an accurate determination of actual concentrations. Treatments were applied to entire case lots of a uniform crop.

The first test was on dark wrappers, with yeast suspensions applied at the three rates, plus an untreated check. Ail four cases were placed in adjoining positions in the third tier of tobacco in a sweat room and allowed to remain for 31 days. Table 18 indicates the changes in moisture content as a result of spraying, in weight, and the corresponding percentages of yeast obtained.

Table 18. Morsture Contents, Weights and Yeast Contents of DARK WRAPPERS

\begin{tabular}{|c|c|c|c|c|c|c|}
\hline \multirow[t]{2}{*}{ Check } & \multicolumn{2}{|c|}{$.75 \%$ Yeast } & \multicolumn{2}{|c|}{$1.00 \%$ Yeast } & \multirow{2}{*}{\multicolumn{2}{|c|}{$1.50 \%$ Yeast }} \\
\hline & Before & After & Before & After & 13efore & \\
\hline \multicolumn{7}{|c|}{ Moisture Contents } \\
\hline 29.45 & 29.28 & 29.91 & 30.07 & 31.64 & 27.01 & 26.69 \\
\hline \multicolumn{7}{|c|}{ Weight in Pounds } \\
\hline 340 & $3221 / 2$ & 321 & $3131 / 4$ & 317 & $3101 / 2$ & 310 \\
\hline \multicolumn{7}{|c|}{ Percentage of Yeast Obtained } \\
\hline 0 & .751 & & 1.079 & & 1.46 & \\
\hline
\end{tabular}

Temperature records in the cases were taken daily by means of spear thermometers, while the room temperature and humidity were obtained with a recorder placed at the same level in the room. Air temperatures were maintained at a little below 90 degrees until near the end of the run, when they were raised to an average of 94 degrees. Temperature gains did not consistently favor any one treatment. After an initial lag by the untreated case, it rose to a peak of 105.5 degrees on the sixth and twentyfifth days. The .75 percent yeast reached 106 degrees on the fourth day and 106.5 degrees on the eighteenth day. The 1.00 percent yeast also had a peak on the fourth day of 107 degrees and on the twentieth day of 106 degrees. This latter figure was also reached by the 1.50 percent yeast on the sixth day, but it failed to exceed 104 degrees after the seventh day. 
At the end of the fermentation period, the cases were opened, the tobacco sampled, weighed and examined. Observations made at the time were as follows:

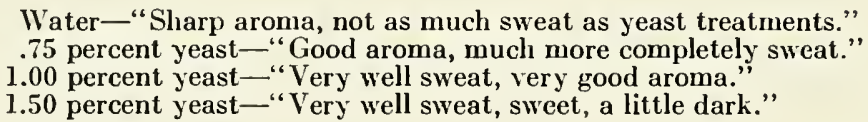

Shrinkage of weight was between 7 and 8 percent of the packed weight, while loss of moisture ranged from 4 to 6.4 percent.

Subsequent to the finish of the fermentation, samples of the tobacco were withdrawn at various times for examination by various experts. Samples were sent to Bloch Bros. Tobacco Company, Wheeling, West Virginia, immediately at the close of the run. Their observations of aroma were that the 1.00 percent yeast had the best aroma, the check and .75 percent yeast were about equal, while the 1.50 percent yeast was not quite up to standard. In June, samples were sent to Mr. C. A. Dickinson of the American Tobacco Company, New York. Cigars were made, using these samples as binders, the other constituents of the cigars being the same. They were placed in plain boxes bearing no trade name, with only the case number for identification. After aging, these cigars were smoked on a blind test basis by numerous persons. Sample comments on the two lots follow:

Check

"Very bitter, could not smoke."

"Strong, not a good smoke."

"Fairly good, taste not bad at first, gets worse as it is smoked."

"Not so good, bitter."
.75 Percent Yeast

"Good to the last inch."

"Very good cigar."

"Too mild, no trace of bitterness."

"Pleasant smoke, not at all bitter."

Repeated tests on these cigars by the same and other observers showed a consistent preference for the yeast treatment. It seemed apparent that the treated tobacco was much more completely fermented and quite ready to use although only a few months old. The untreated tobacco showed more of the raw characteristics. The difference produced by only the binder was pronounced, but it is commonly recognized that if one component of a cigar is bitter, it will adversely affect the taste of the entire cigar.

Parallel tests on seconds and No. 2 seconds were started soon after the test on darks. These will not be discussed in detail since results simply confirmed previous findings. Temperature differences, or net gains, were not great with the seconds. However, the behavior of the No. 2 seconds was sharply different. The yeast treatment maintained a higher temperature from start to finish, the differences ranging from 2 to 13 degrees above the check. A maximum temperature of 112 degrees, with a room temperature of 97 degrees, was obtained on the tenth day, while the untreated peak was 107.5 degrees on the same date. 


\section{Summary}

Commercial tests on yeast application to Havana Seed binder tobacco indicate the following:

1. The grade known as "darks" was greatly benefited by applications of yeast up to 1.00 percent. The treated tobacco had a more completely fermented appearance and a more pleasant aroma.

2. The untreated darks and the .75 percent yeast-treated were used as binders on cigars where the other components were identical. The results of smoking tests were overwhelmingly in favor of the cigars with the treated binders.

3. Differences with seconds were not as great as with darks. However, appearance and aroma of the treated tobacco were superior to the check.

4. Differences with No. 2 seconds were consistently in favor of the treated tobacco in temperature gain, appearance and aroma. 



University of

Connecticut

Libraries

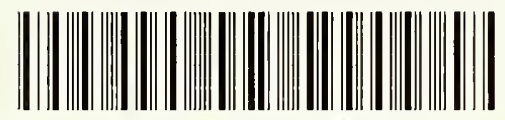

39153029045350 
